\title{
Exposing wind stress as a driver of fine-scale variation in plant communities
}

\author{
Momberg, Mia
}

2021-05

Momberg , M , Hedding, D W , Luoto , M \& le Roux , P C 2021, ' Exposing wind stress as a driver of fine-scale variation in plant communities ', Journal of Ecology , vol. 109 , no. 5 , pp. 2121-2136 . https://doi.org/10.1111/1365-2745.13625

http://hdl.handle.net/10138/340195

https://doi.org/10.1111/1365-2745.13625

acceptedVersion

Downloaded from Helda, University of Helsinki institutional repository.

This is an electronic reprint of the original article.

This reprint may differ from the original in pagination and typographic detail.

Please cite the original version. 


\section{Journal of Ecology}

1

2 MS MIA MOMBERG (Orcid ID : 0000-0002-8901-9271)

3 DR DAVID W HEDDING (Orcid ID : 0000-0002-9748-4499)

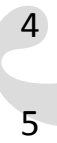

5

6 Article type : Research Article

7 Editor: Robert Björk

8

9 Exposing wind stress as a driver of fine-scale variation in plant communities

10

11 Mia Momberg ${ }^{1}$, David W. Hedding ${ }^{2}$, Miska Luoto $^{3}$ and Peter C. le Roux ${ }^{1}$

12 'University of Pretoria, South Africa ${ }^{2}$ University of South Africa, South Africa ${ }^{3}$ University of Helsinki,

13 Finland

14 M. Momberg (miamomberg@gmail.com)

15

16

17

18

19

20

21

22

23

24

This article has been accepted for publication and undergone full peer review but has not been through the copyediting, typesetting, pagination and proofreading process, which may lead to differences between this version and the Version of Record. Please cite this article as doi: $\underline{10.1111 / 1365-2745.13625}$

This article is protected by copyright. All rights reserved 
34 Abstract

35 1. The effects of temperature and precipitation, and the impacts of changes in these climatic

36 conditions, on plant communities have been investigated extensively. The roles of other climatic

37 factors are, however, comparatively poorly understood, despite potentially also strongly

38 structuring community patterns. Wind, for example, is seldom considered when forecasting

39 species responses to climate change, despite having direct physiological and mechanical impacts

40 on plants. It is, therefore, important to understand the magnitude of potential impacts of changing

41 wind conditions on plant communities, particularly given that wind patterns are shifting globally.

42 2. Here, we examine the relationship between wind stress (i.e. a combination of wind exposure 43 and wind speed) and species richness, vegetation cover and community composition using fine44 scale, field-collected data from 1440 quadrats in a windy sub-Antarctic environment.

45 3. Wind stress was consistently a strong predictor of all three community characteristics, even 46 after accounting for other potentially ecophysiologically important variables, including $\mathrm{pH}$, 47 potential direct incident solar radiation, winter and summer soil temperature, soil moisture, soil 48 depth, and rock cover. Plant species richness peaked at intermediate wind stress, and vegetation 49 cover was highest in plots with the greatest wind stress. Community composition was also related 50 to wind stress, and, after the influence of soil moisture and $\mathrm{pH}$, had a similar strength of effect as 51 winter soil temperature. 
52 4. Synthesis: Wind conditions are, therefore, clearly related to plant community characteristics in

53 this ecosystem that experiences chronic winds. Based on these findings, wind conditions require

54 greater attention when examining environment-community relationships, and changing wind

55 patterns should be explicitly considered in climate change impact predictions.

56 Keywords: community composition, fine-scale, plant community, species richness, vegetation

57 cover, wind

\section{Introduction}

60 Recent changes in climate have impacted all aspects of ecological communities, including species

61 richness, total abundance, biomass, cover and species composition (e.g. Menéndez et al., 2006;

62 Kardol et al., 2010; Liu et al., 2018). Given the implications of these community-level changes for

63 conservation, ecosystem services and human health, predicting how further changes in climate will

64 affect communities is a key challenge in ecology (Kolstad and Johansson, 2011; Pecl et al., 2017).

65 While some trends, like species range shifts, have been observed fairly consistently (e.g. Morueta-

66 Holme et al., 2015; Freeman et al., 2018), exceptions have also been noted (e.g. Lenoir et al.,

67 2010; Zhang et al., 2019), suggesting that some key factors or processes still need to be accounted

68 for. Indeed, many studies forecasting ecological responses to climate change consider only

69 temperature and precipitation as climatic variables, and do not account for other components of

70 climate. For example, the ten climatic variables most commonly used in plant species distribution

71 modelling studies all just quantify aspects of temperature and precipitation (Gardner et al., 2019).

72 Other climatic factors may, however, also be influential in determining individual species

73 distributions and, as a result, community characteristics (Barton, 2017; Cherry and Barton, 2017;

74 Maclean, 2020). Therefore, to improve the quality of the predictions of the ecological impacts of

75 climate change, it is important to consider a more comprehensive set of climatic variables that

76 directly affect plant performance (Gardner et al., 2019). Indeed, other variables, such as snow

77 cover duration and solar radiation, can have profound effects both on individual species and on

78 communities (see Bennie et al., 2008; Austin and Van Niel, 2011; Niittynen and Luoto, 2018). For

79 example, decreasing snow cover duration in the Arctic has a larger effect on species' probability

80 of becoming locally extinct than rising temperatures alone (Niittynen et al., 2018). Thus, a more

81 thorough understanding of the impacts of climatic factors, extending beyond conventional 
measures of temperature and precipitation, is required in order to more accurately predict how communities may be affected by changing climates (Mod et al., 2016).

Wind is a climatic variable that is currently underexplored as a driver of community

85 patterns (see Table 1), despite representing an important stress and disturbance for many different 86 taxa (Watanabe and Hasumi, 2005; Bintanja et al., 2014; Combes and Matano, 2018). It is 87 relatively well understood how extreme winds (e.g. hurricanes and tornadoes) affect individuals, 88 species, and communities (Mitchell, 2012; Møller, 2013; Behie et al., 2014; Xuan and Chang, 89 2014). However, these extreme conditions are limited in time and space (Nyberg et al., 2007; 90 Lugo, 2008), and the impacts of chronic (i.e. continuous) wind conditions may be important but

91 have received little focused attention. Exposure to wind has clear physiological impacts on plants, 92 whereby, for example, plants typically close their stomata during windy conditions to reduce the 93 rate of transpiration, consequently leading to lower rates of photosynthesis (Grace, 1977; de 94 Langre, 2008). In addition, winds may desiccate the soil, creating a moisture stress for plants 95 (Bertiller et al., 1996; Fitzgerald and Kirkpatrick, 2017), and redistribute litter which has an effect 96 on soil temperature and nutrient content (Fahnestock et al., 2000). Wind may also have a range of 97 mechanical impacts on plants, with, for example, strong winds potentially tearing leaves, causing 98 abrasion and desiccation (Hadley and Smith, 1983; Hadley and Smith, 1986; de Langre, 2008; 99 Gardiner et al., 2016), uprooting individuals (Yang et al., 2014), and causing flowers and fruits to 100 be shed (e.g. Lahav and Zamet, 1999). As a result, lower wind speeds are typically associated with 101 faster plant growth rates and higher productivity (e.g. Bang et al., 2010), although physiological 102 responses to wind conditions may be species-specific (Onoda and Anten, 2011). Further, wind can 103 shape the outcome of plant-plant interactions (severity-interaction-relationships; le Roux and 104 McGeoch, 2010). Therefore, wind has the potential to directly affect vegetation patterns, from 105 altering individual species' dominance (Okitsu and Ito, 1984) to impacting the distribution of 106 different plant communities (Williams and Ashton, 1987; Lynch and Kirkpatrick, 1995; see Table 1071 for an illustrative summary of what is currently known about the impacts of wind on vegetation). 108 Consequently, differences in chronic wind conditions between sites and/or years has considerable 109 potential to drive spatio-temporal variations in plant communities.

110 Wind stresses and disturbances may vary greatly over short distances (Katsaprakakis and 111 Christakis, 2012; Chiras, 2017), and could therefore potentially contribute to fine-scale variation 112 in ecological communities. For example, wind velocity can vary around individual plants 
113 (Combrinck et al., 2020) and models that do not account for fine-scale variation in wind patterns 114 do not accurately predict seed dispersal (Lönnell et al., 2015). Variability in wind speed has also, 115 for instance, been related to fine-scale differences in plant height, species richness, growth form 116 diversity, and community type (Whitehead, 1954; Whitehead, 1959; Wilson, 1959). Nevertheless, 117 wind is seldom considered as a driver of fine-scale variation in community patterns (see review by 118 Gardner et al., 2019), and despite technological advances that have improved measurement and 119 modelling of wind conditions, little work has recently examined the influence of wind on plant 120 communities (although, see, e.g. Fitzgerald and Kirkpatrick, 2017; Sun et al., 2019; Sparacino et 121 al., 2020; and Table 1). In addition, the reciprocal effect of vegetation on wind patterns, has also 122 attracted limited attention (although see, e.g., Combrinck et al., 2020).

\section{Based on our current understanding of the ecological impacts of wind, variation in}

124 prevailing wind conditions at fine spatial scales is likely to affect multiple measures of plant

125 community structure. As wind exposure increases, vegetation cover generally declines due to wind 126 pruning and slower growth rates (Bang et al., 2010; Gardiner et al., 2016), as evident, for example,

127 on New Zealand's off-shore islands (McGlone, 2002). Species richness may also decline in 128 increasingly windy microclimates, especially in species-poor environments. However, in more 129 species-rich communities, species may instead show a pattern of replacement along a wind stress 130 gradient due to inter-specific differences in wind tolerance (i.e. more wind-tolerant species replace 131 taller and/or more competitive species that are less tolerant of wind stress; e.g. Burke et al., 1989; 132 Fernández-Palacios and Nicolás, 1995). Under such a scenario species richness would be predicted 133 to remain relatively constant while species composition shifts in response to greater wind stress 134 (i.e. a type of Gleasonian distribution; Gleason, 1939). 136 decades ago (Wilson, 1959; see also Whitehead, 1954; Whitehead, 1959), but this issue has yet to 137 be explicitly and thoroughly addressed (see e.g. Sutherland et al., 2017). Furthermore, 138 understanding how wind, and changes in wind patterns, affects biodiversity is increasingly 139 relevant as, over the last decade, mean wind speeds have accelerated globally, with the largest 140 changes happening in the Southern Ocean (Young and Ribal, 2019; Zeng et al., 2019), and current 141 predictions suggesting that this trend will continue in the long-term (Jeong and Sushama, 2019; 142 Zeng et al., 2019). Therefore, in this study, the impact of wind on fine-scale vegetation 143 characteristics was assessed by examining the relationship between wind stress (i.e. a combination 
144 of wind exposure and wind speed) and 1) vascular plant species richness, 2) species cover, and 3)

145 species composition in a wind exposed environment, after accounting for other potentially

146 ecophysiologically important variables (Mod et al., 2016).

147

$148 \quad$ Materials and methods

149 Study site

150 This study was conducted on the isolated sub-Antarctic Marion Island (46 $\left.54^{\prime} \mathrm{S}, 37^{\circ} 45^{\prime} \mathrm{E}\right)$. The

151 sub-Antarctic provides an ideal study system to examine the ecological consequences of chronic

152 winds as the region experiences consistently strong daily wind conditions (Pendlebury and Barnes-

153 Keoghan, 2007; le Roux, 2008). Terrestrial habitats of Marion Island exhibit broad gradients of

154 wind stress due to their complex topography, with sites ranging from sheltered to exposed often

155 separated by only short distances. Marion Island lies approximately halfway between Africa and

156 Antarctica, covers an area of $293 \mathrm{~km}^{2}$, and rises to $1240 \mathrm{~m}$ a.s.l. (Boelhouwers et al., 2008). The

157 island is situated in the "roaring forties", the region between 40 and $50^{\circ} \mathrm{S}$, that experiences strong

158 and relatively consistent westerly winds (Pendlebury and Barnes-Keoghan, 2007; le Roux, 2008)

159 which can affect pedogenesis, vegetation growth, soil frost formation and aeolian transport of

160 particles (Hedding et al., 2015). Gale force winds blow on $>100$ days per annum on Marion Island

161 (with relatively consistent directionality; le Roux, 2008). The island has a hyper-oceanic climate

162 (characterized by cool temperatures with little diurnal and seasonal variation) and high humidity,

163 with near complete cloud cover and precipitation on most days (le Roux, 2008). The mean daily

164 maximum and minimum temperatures are $8.7^{\circ} \mathrm{C}$ and $3.2^{\circ} \mathrm{C}$ respectively, and the mean annual

165 precipitation is c. $1800 \mathrm{~mm}$ (recorded at the island's meteorological station which is $\sim 1 \mathrm{~km}$ away

166 from the study site; average from 2008 - 2018).

167 Data collection

168 Data were collected from early 2016 to early 2017 on the eastern side of Marion Island, with

169 sampling focused in a topographically-, geologically- and biotically-heterogenous area

170 (comprising a smooth pre-glacial lava flow north of the Van den Boogaard river and a rugged

171 post-glacial lava flow south of the river; Fig. 1). A survey approach was used that has previously

172 been applied in other high-altitude and high-latitude systems (e.g. le Roux et al., 2013b;

This article is protected by copyright. All rights reserved 
173 Kemppinen et al., 2019; Niittynen et al., 2020a), where vegetation composition and abiotic

174 conditions are measured across steep environmental gradients within a single landscape unit

175 (avoiding differences in macroclimate and regional species pools). Nine grids of $8 \times 20 \mathrm{~m}$ were

176 sampled, each comprising 160 contiguous quadrats of $1 \mathrm{~m}^{2}$ (resulting in 1440 quadrats sampled in

177 total; Figure 1, Table 2). These grids encompassed fellfield, mire vegetation, and fern-dominated

178 slopes, and contained 18 vascular plant species. Grids were located to sample the full range of

179 conditions within the site, covering the range of vegetation types, vegetation cover and topography

180 present. The distance between grids was $70-915 \mathrm{~m}$, with the grids covering an altitudinal range of

181 c. 40 to $100 \mathrm{~m}$ a.s.1. Individual grids, in turn, were orientated to encompass as much local

182 environmental variability as possible.

183 Within each of the $1 \mathrm{~m}^{2}$ quadrats several abiotic and biotic variables were measured. The

184 cover and identity of all vascular plant species in each quadrat were recorded and then used to

185 determine the species richness and composition for each quadrat. Percentage plant cover, rock

186 cover (i.e. the cover of rocks or boulders large enough to inhibit plant growth) and bare soil cover

187 were visually estimated. Soil depth was measured using a thin metal rod (diameter of $8 \mathrm{~mm}$ ) at

188 three points randomly located in each quadrat, and an average soil depth then calculated for the

189 quadrat (where soil depth exceeded $60 \mathrm{~cm}$, a value of $70 \mathrm{~cm}$ was assigned). The slope and aspect

190 of each quadrat were recorded and these values were then used to calculate potential annual direct

191 incident radiation (PDIR; McCune and Keon, 2002; McCune, 2007). Soil samples were taken

192 from 16 - 32 quadrats per grid and used to determine soil $\mathrm{pH}$ in the laboratory using the $\mathrm{CaCl}_{2}$

193 method (Hendershot et al., 2008). Soil pH was then interpolated to the unsampled quadrats using

194 bilinear interpolation (Bovik, 2009).

195

Instantaneous soil temperature and soil moisture measurements were taken in each quadrat

196 in June, July and October 2016 and January and April 2017. These readings were only taken on

197 days when there had been at least 24 hours since the last rainfall event. Volumetric soil moisture

198 content was measured using a handheld time-domain soil moisture meter (using $7.5 \mathrm{~cm}$ probes;

199 FieldScout TDR 300; Spectrum Technologies), and soil temperature was measured using a

200 corkscrew thermometer (EXTECH Instruments, TM40) at a depth of $5 \mathrm{~cm}$. To test whether the

201 order in which measurements were taken had an effect on soil moisture or temperature readings

202 (i.e. testing for an effect of time of the day), the grid which was measured first was revisited at the

203 end of the measurement period and partly remeasured ( 20 quadrats). The average difference in

This article is protected by copyright. All rights reserved 
204 instantaneous soil moisture readings between the initial and final measurements in resampled 205 quadrats was $0.8 \%$, and, therefore, the raw data for soil moisture readings were used in analyses.

206 Soil temperature, however, showed a significant difference (t-test: $p<0.001)$ between the

207 temperature measured at the start of the measurement time period versus the end of the

208 measurement period for the quadrats which were remeasured. Therefore, to account for the effect

209 of the measurement time on soil temperature, readings were corrected using a linear adjustment.

210 This correction was based on soil temperature data logged in $3-9$ cells per grid using temperature

211 loggers (Thermochron iButton DS1921G; Maxim Integrated), with data from the specific day on

212 which instantaneous measurements were made being used (following le Roux et al., 2013a).

213 Soil temperatures in the winter months were positively correlated (June and July), while

214 there was minimal correlation between winter and summer temperatures (Figure A1). Therefore,

215 one measurement of summer soil temperature (January; mid-summer) and one measurement of

216 winter soil temperature (June; mid-winter) were used in all subsequent analyses. Soil moisture was

217 significantly positively correlated across all months (Figure A2), and, therefore, moisture data

218 from only one month (October) were included in further analyses.

219 Wind speed and direction were measured at 17 locations across Marion Island using two

220 sonic anemometers (Gill Windsonic: Gill Instruments, UK), mounted at $0.5 \mathrm{~m}$ and $1 \mathrm{~m}$ above

221 ground at each of the locations. The anemometers measured wind speed and direction in the

222 horizontal plane (two-dimensional) at a $0.01 \mathrm{~m} . \mathrm{s}^{-1}$ resolution, with measurement accuracy of $2 \%$

223 (at $12 \mathrm{~m} \cdot \mathrm{s}^{-1}$ ). Wind speed and direction were sampled at $0.5 \mathrm{~Hz}$, with mean direction and speed

224 logged every 10 minutes using a CR300 datalogger (Campbell Scientific, USA). Both the

225 anemometers and the logger were powered using a $12 \mathrm{~V} \mathrm{DC}$ battery continuously charged using a

$22625 \mathrm{~W}$ solar panel. Wind direction data for the study site showed one clear and dominant wind

227 direction, and, therefore, only the dominant wind direction was extracted from the wind station

228 located closest to the study site ( $<700 \mathrm{~m}$ from the furthest grid) over a 12-month period (April

2292018 - March 2019). Wind at the study site predominantly comes from a north-westerly direction

$230\left(68 \%\right.$ of readings were from $260-330^{\circ}$ from $\left.\mathrm{N}\right)$, with the strongest wind speeds being even more

231 limited to the north-westerly sector ( $88 \%$ of all wind speeds greater than $11 \mathrm{~m} . \mathrm{s}-1$ were recorded

232 between $260-330^{\circ}$; Figure 1; in agreement with long-term data from the island's weather station;

233 le Roux, 2008).

This article is protected by copyright. All rights reserved 
235 Phantom 4 Pro fitted with a 20-megapixel camera) at a ground sample distance of $0.7 \mathrm{~cm}$ during 236 April 2019. The aerial images from the UAV were processed in Agisoft Photoscan using the 237 principle of structure-from-motion to produce a point dense cloud which in turn was used to 238 generate a Digital Surface Model (DSM) at $2 \mathrm{~cm}$ resolution, which captures the elevation of the 239 surface. From the DSM's, a within-grid wind exposure metric was calculated for each $1 \mathrm{~m}^{2}$ 240 quadrat using the Wind Effect module in SAGA-GIS (Conrad et al., 2015), specifying the wind 241 direction as North-West (with the majority of the wind coming from $292-338^{\circ}$; based on the data 242 from the wind station at the site). The minimum, maximum, and mean of the wind effect values 243 were extracted for each quadrat. Wind effect is a dimensionless index, where values below 1 244 indicate areas that are sheltered from wind and values above 1 indicate areas that are exposed to 245 wind in terms of the specified wind direction (Böhner and Antonić, 2009). To account for 246 differences in coarser-scale wind stress between grids (since some grids were more wind-exposed 247 than others; Fig. 1), the mean simulated wind speed for each grid was extracted from a 248 computational fluid dynamics (CFD) model of Marion Island (maximum $50 \mathrm{~m}$ resolution) using

249 ANSYS Fluent 2019R3 (Ansys, USA). The CFD model uses a full-scale digital elevation model of 250 Marion Island (DRDLR, 2019) and simulates air flow over the topology by iteratively solving a 251 set of partial differential equations (the Reynolds-Averaged Navier Stokes Equations; see Versteeg 252 and Malalasekera, 2007 for a detailed consideration of CFD; and Cindori et al., 2018 for a recent 253 implementation). A westerly wind was assumed as the free-stream condition with a reference 254 speed of $5 \mathrm{~m} \cdot \mathrm{s}^{-1}$ at $1.5 \mathrm{~m}$ above ground, based on measured data from the wind stations. The model 255 includes considerations for the atmospheric boundary layer and the effect of the Coriolis force 256 (Breedt et al., 2018). This estimate of grid-level wind speed was multiplied by quadrat-level wind 257 index indices (for minimum, maximum, mean, and range wind stress) to estimate wind stress 258 values that are comparable across and within grids (i.e. accounting for grids differing considerably 259 in landscape-level wind stress). The wind stress metric provides relative values, enabling 260 comparisons between sites within this particular study system, where higher values indicate higher 261 wind stress. Here wind stress represents the combined influence of wind exposure to the dominant 262 wind direction and the simulated mean wind speed at each grid when the wind is blowing from the 263 dominant wind direction. These values, therefore, provide an estimate of the mean physical and 264 mechanical strain that plants experience (i.e. representing chronic wind stress). The resulting wind 
265 stress metrics were highly correlated ( $r>|0.8|$; Figure A3), and, therefore, only maximum wind 266 stress was used in subsequent analyses.

\section{Statistical analyses}

268 None of the predictor variables in the final dataset were strongly or significantly correlated 269 with each other $(r<|0.8|$ and Variance Inflation Factor $<3.1$; Figure A4). The relationship 270 between species richness (and cover) and predictor variables was analysed using three different 271 statistical methods to reduce uncertainties due to modelling approach: generalized linear models 272 (GLZ; Müller, 2012), generalized additive models (GAM; Wood and Augustin, 2002), and 273 generalized boosted regression models (GBM; Friedman et al., 2000; Friedman, 2001). These 274 three methods were chosen due to their differing flexibility and complexity. All of the statistical 275 methods were run assuming a Poisson (for species richness) or quasibinomial (for vegetation 276 cover; which was significantly over-dispersed) distribution.

277 For all three statistical methods, a first model was run with PDIR, soil depth, rock cover,

278 winter temperature, summer temperature, moisture, and $\mathrm{pH}$ as predictor variables (hereafter 279 referred to as the "simple model"). A second model was then run with all of the above variables, 280 as well as the maximum wind stress (hereafter referred to as the "full model"). The GLZs included 281 quadratic terms for all predictor variables to allow for non-linear relationships. For GAMs, the 282 initial degree of smoothness for each predictor was set to four. The tree complexity was set to 6 283 for GBMs and the tree threshold to 1000. To determine whether the addition of wind stress 284 improved the performance of the models, each pair of simple and full models from GAMs and 285 GLZs were compared using a likelihood ratio test (for species richness) and an F-test (for 286 vegetation cover). Similar model comparisons are not possible for GBMs, but response curves and 287 variable importance could be compared between GBMs and the other two methods. Variable 288 importance for GAMs and GLZs was calculated by comparing the Pearson correlation between 289 predictions made on the original data and predictions made on the data where the predictor 290 variable of interest has been randomly shuffled (following Niittynen and Luoto, 2018). The 291 calculations of variable importance were calculated 10 times and the mean importance value 292 reported.

293 Species composition was modelled using non-metric multidimensional scaling (nMDS) 294 and permutational multivariate analysis of variance (PERMANOVA) based on species occurrence. 
295 Two dimensions, 200 random starts and the standard transformation (Wisconsin double

296 standardization) were used in nMDS analyses. Nestedness analyses were also conducted on the 297 species composition data to determine whether species were nested along the wind stress gradient 298 (Ulrich, 2009). The species-site matrix was first ordered by maximum wind stress, and the 299 nestedness metric based on Overlap and Decreasing Fill (NODF) was calculated. NODF is less 300 prone to type I statistical errors and is insensitive to matrix size and shape, and, therefore, provides 301 a more conservative approach than other nestedness metrics (Almeida-Neto et al., 2008). Finally, 302 the nestedness analysis was complemented by calculating the overall beta diversity between 303 quadrats using the Sørensen dissimilarity index, with the contribution of species turnover 304 (measured as Simpson dissimilarity) and nestedness (measured as the nestedness-resultant fraction 305 of the Sørensen dissimilarity index) being partitioned to explain the observed differences in 306 community composition (Baselga and Orme, 2012).

307 All analyses were run in R statistical software, version 3.5.0 (R Core Team, 2018), using 308 additional functions from the vegan (Oksanen et al., 2018), mgcv (Wood, 2006), spind (Carl et al., 309 2018), and betapart (Baselga et al., 2018) libraries.

310

\section{$311 \quad$ Results}

312 Wind stress ranged from 4.5 to 8.5, with grid one experiencing the overall lowest wind stress, and 313 grid four the highest wind stress (Figure 2). Species richness varied between zero and eight species 314 per $1 \mathrm{~m}^{2}$ quadrat, and between 9 and 15 species per grid (Figure 3), while vascular plant cover 315 varied between a minimum of zero and a maximum of $100 \%$ (Figure A5).

316 The full model, including wind stress, performed significantly better than the simple model 317 for species richness in the GAM, and marginally significantly so in the GLZ. For vegetation cover 318 the full model performed significantly better in both statistical approaches (GLZ and GAM; 319 likelihood ratio test and F-test, $\mathrm{p}<0.05$; Table A1). The full model for species richness improved 320 the deviance explained by $0.8 \%$ for the GLZ and by $3.5 \%$ for the GAM relative to the simple 321 models that did not include a measure of wind stress. For vegetation cover, the full model 322 improved the deviance explained by $1.4 \%$ for the GLZ and by $1.4 \%$ for the GAM (Table A1). 
324 the top five predictor variables (i.e. on the basis of variable importance; Table 3; wind stress was

325 the second most important predictor in the GBM model, Table A2). Response curves from the

326 GAM model for species richness showed that species richness has a complex relationship with

327 maximum wind stress, with the highest species richness observed at intermediate maximum wind

328 stress (Figure 4, with raw data shown in Figure A6; similar response curves were observed from

329 the GLZ model, Fig. A8; and for the GBM model, Fig. A10). The addition of wind stress to the

330 model changed the shape of the response curve between species richness and PDIR (from negative

331 to nearly horizontal), winter soil temperature (the slope of the positive response becomes less

332 steep), and summer soil temperature (remains hump-shaped, but high temperatures result in a

333 smaller drop in species richness). Species richness also showed non-linear relationships with both

334 rock cover and $\mathrm{pH}$ (which were also consistently in the top five predictors), where species richness

335 peaked at c. $60 \%$ rock cover and $4.6 \mathrm{pH}$ (Figure 4 ).

$336 \quad$ Vegetation cover was significantly predicted by maximum wind stress, and wind stress

337 was the second most important predictor when modelling vegetation cover for both the GLZ and

338 the GAM (Table 3; and third most important in the GBM model, Table A2). The response curves

339 for vegetation cover showed that maximum wind stress had a valley-shaped relationship with

340 vegetation cover (Figure 5 and Figure A7; see Fig. A9 and A11 for GLZ and GBM response

341 curves which showed similar patterns). Rock cover had a strong negative relationship with

342 vegetation cover, and was the most important predictor in both statistical approaches (Table 3).

343 All eight of the predictor variables in the full model contributed significantly to explaining

344 variation in species composition, and together explained $33.9 \%$ of the variation (the simple model

345 explained $32.4 \%$ ). Wind stress was the fourth most important predictor in explaining species

346 composition, after soil moisture, $\mathrm{pH}$, and winter soil temperature. Species composition was weakly

347 nested by wind stress, with $\mathrm{NODF}=31.0$, whereas $\mathrm{NODF}=57.9$ when the species matrix is

348 arranged to maximize nestedness. This result was mirrored by the partitioning of beta diversity

349 into species turnover and nestedness, where an overall Sørensen dissimilarity index value of 0.996

350 (indicating high dissimilarity in the species composition between quadrats) was predominantly

351 driven by species turnover (0.994), with nestedness having a much smaller effect (0.003). 


\section{Discussion}

354 Wind stress was consistently prominent in explaining fine-scale spatial variation in species

355 richness, vegetation cover, and species composition, as evidenced both by models including wind

356 stress performing better than models without wind stress and by wind stress repeatedly having 357 among the highest relative importance values. These results agree with findings across broader 358 scales, where, for example, wind protection is important in determining the distribution of high359 altitude forests and tree sapling growth (Sparacino et al., 2020), and wind patterns improved the 360 accuracy of future temperature forecasts and resulting predictions of climate refugia (Ashcroft et 361 al., 2009).

362 Both species richness and species cover were significantly related to wind stress. Species 363 richness responded non-linearly to wind stress, with the highest species richness at intermediate 364 maximum wind stress. This suggests that in ecosystems with high wind stress, such as sub365 Antarctic islands, areas that do not have sheltered microsites have a constrained species richness, 366 and that the largest number of species co-occur where the maximum stress conditions in an area 367 are neither entirely sheltered nor exposed. Vegetation cover follows the same trend as species 368 richness, where maximum wind stress is one of the key predictors. Wind stress and vegetation 369 cover have a non-linear relationship (i.e. both low and high maximum wind stress values are 370 correlated with higher vegetation cover), but the highest vegetation cover is found in microsites 371 with the highest maximum wind stress. It is possible that in this system where bryophytes can be 372 co-dominant (e.g. in both the wettest habitats; Smith and Steenkamp, 2001; Smith et al., 2001), 373 that at high wind speeds evapotranspiration causes too great a moisture stress for bryophytes 374 (which are poikilohydric and are highly dependent on external water availability; Vitt et al., 2014), 375 allowing vascular plants to achieve greater cover.

376 Species composition was also significantly related to wind stress, and differed strongly 377 between quadrats, driven chiefly by species replacement. The low nestedness exhibited by 378 vascular plant species along the wind stress gradient, which matches the observation that species 379 richness did not decline uniformly with increasing wind stress, suggests that species may be 380 replacing each other as wind conditions become progressively more stressful. For example, on 381 Marion Island, the alien grass Agrostis stolonifera, is limited to sites which are sheltered due to its 382 lack of supportive tissue, while the indigenous congeneric A. magellanica grows in more wind 383 exposed locations (Pammenter et al., 1986). Further, presumably due to the wind-sheltered nature 
384 of streambanks, Agrostis stolonifera disproportionately invades these communities, but is absent

385 from windier habitats (Gremmen et al., 1998). Irrespective of the mechanism driving the influence

386 of wind on community composition, these results agree with previous studies in other temperature-

387 limited systems that have also identified wind (acting, e.g., via erosion) as a driver of variation in

388 species composition (Vonlanthen et al., 2006a; le Roux and Luoto, 2014). Therefore, in terms of

389 species richness, cover and composition, wind is an important driver of plant community structure

390 at fine-scales in an environment that is exposed to chronic winds.

391 The other abiotic variables that were strongly related to vascular plant richness, cover and

392 composition exhibited patterns consistent with other studies conducted at high altitude and/or

393 latitude sites. For example, $\mathrm{pH}$ was a consistently strongly correlated with species richness, in

394 agreement with findings from other temperature-limited systems (e.g. Vonlanthen et al., 2006b;

395 Filibeck et al., 2019). Soil moisture played the largest role in driving community composition, and

396 this variable has been highlighted as a key driver of species composition in other low-energy

397 systems (le Roux et al., 2013a). Indeed, wind and soil moisture may potentially have an interactive

398 relationship, with strong winds desiccating upper soil layers (Bertiller et al., 1996). Because wind

399 stress was related to plant community properties even after accounting for these other abiotic

400 variables, these results clearly highlight the importance of wind in driving variation in floral

401 communities.

402

403 Wind as a globally underexplored environmental driver

404 While wind may be important in high latitude and high altitude regions (e.g. Whitehead, 1954;

405 Wilson, 1959 and this study), and experiments have shown it to have widespread effects on plant

406 growth in other regions too (Wilson, 1959), it is still partly unclear if the patterns observed here

407 can be generalized to other systems. At a minimum, it is likely that wind will be important in (1)

408 areas with strong winds (chronic and/or extreme winds) as it is a mechanical stress, (2) areas with

409 fine and loose material available for aeolian transport (e.g. due to erosion, deposition and wind

410 scouring in dune environments; Nylén et al., 2015; Nylén and Luoto, 2015), (3) dry areas where

411 wind enhances evaporation and the potential for plants to experience greater moisture stress

412 (Zhang et al., 2007), (4) areas with thin soils which are more susceptible to desiccation (Bertiller

413 et al., 1996), and (5) Arctic and alpine areas where it affects snow drift (Sturm et al., 2001; Dadic

This article is protected by copyright. All rights reserved 
414 et al., 2010). Wind may also have an indirect effect by interacting with other climatic factors (see

415 e.g. Kullman and Loyer, 2005; Ashcroft et al., 2009). As a result, the large recent changes in

416 global wind patterns may have direct consequences for species distributions and interactions

417 between species (Young et al., 2011; Young and Ribal, 2019), as well as indirect impacts (e.g. by

418 affecting seed dispersal; Kling and Ackerly, 2020).

419 Predictions of the ecological impacts of changing wind conditions may be complicated by

420 species- and site-specific responses. For example, wind may differentially impact on groups of

421 species within communities. Since understory species are less exposed, for example in forest

422 communities, it is expected that canopy species will show the greatest responses to changes in

423 wind (as observed for changes in temperature; Mau et al., 2018). Further, species growing on ridge

424 crests or slopes will likely be more affected than those growing in protected valleys, since changes

425 to wind speed and/or direction in wind exposed locations will be less buffered by other vegetation

426 or topographic features. An added challenge in making predictions on the impacts of changing

427 wind conditions is that altered wind patterns may contribute to the development of "novel

428 climates", representing climatic conditions not currently present elsewhere (sensu Williams and

429 Jackson, 2007; Dahinden et al., 2017). Plants and animals may lack adaptations to changes in wind

430 conditions; similar to some species' inability to adapt fast enough to recent changes in temperature

431 and precipitation (e.g. Parmesan and Hanley, 2015; Gómez-Ruiz and Lacher Jr, 2019; Radchuk et

432 al., 2019). Therefore, the impacts of changes in wind patterns on plant communities will likely be

433 dependent on interactions with microclimatic and/or topographic conditions, and will vary

434 between habitat types and species groups.

435 To further understand the ecological impact of wind, future studies should investigate not 436 only community-level metrics (e.g. as in this study), but also the responses of the individual 437 species that comprise the community. Species may, for example, respond to wind stress through 438 trading-off resources between different processes or traits, as seen in response to changes in other 439 climatic factors (Gandin et al., 2011; Liu et al., 2013). Indeed, recent evidence has shown that, for 440 example, some plant species respond to higher wind speeds by increasing their foliar silicon 441 content (which may provide protection against mechanical stress; Song et al., 2020). Functional 442 traits have been used to examine how species react to changes in other environmental variables 443 (e.g. Bjorkman et al., 2018; Niittynen et al., 2020b; Thomas et al., 2020), and traits related to 444 resource allocation (e.g. specific leaf area) and leaf toughness (e.g. leaf dry matter content and 
445 tensile strength) may provide useful metrics for quantifying functional variation within species in 446 response to spatio-temporal variation in wind patterns.

Here we show that spatial variation in wind stress has a defining impact on vegetation 448 communities in an ecosystem that experiences chronic winds. Therefore, temporal variation in 449 wind patterns, which are currently shifting due to global climate change (Young et al., 2011; $450 \quad$ Young and Ribal, 2019; Zeng et al., 2019), may also likely affect plant community characteristics 451 through time, in the same way that wind currently affects their spatial patterning. The growing 452 availability of wind data at a coarse spatial scale needs to be (1) examined in the context of 453 landscape-level biological patterns (i.e. related to topography), and (2) refined to also describe 454 variation in wind characteristics at the scales affecting individual plants and local communities 455 (Maclean, 2020). Wind has been an understudied climatic driver of biotic communities for more 456 than 60 years (Wilson, 1959), and, especially in light of the global challenge of climate change, it 457 is now time to advance our understanding of where, and to what extent, wind acts as a driver of 458 vegetation patterns at multiple spatial scales.

459

\section{Acknowledgements}

461 This research was supported by the National Research Foundation's South African National 462 Antarctic Programme (grant number 93077, 110726 and 110723) and was conducted under 463 permits from the Prince Edward Islands Management Committee (PEIMC1/2013). MM received 464 funding from the South African National Research Foundation. We thank E. Mostert, N. Mhlongo, 465 J. Schoombie and J. van Berkel for field assistance. We thank P. Niittynen for advice on statistical 466 analyses. The authors declare no conflict of interest.

\section{7}

468 Data availability statement

469 Data will available from the Dryad Digital Repository from 1 January 2022:

470 https://doi.org/10.5061/dryad.547d7wm7k (Momberg et al., 2021).

471

\section{$472 \quad$ Author contributions}


473 PCLR, ML and MM conceived the ideas and designed methodology; MM, PCLR and DWH

474 collected and processed the data; MM and PCLR analysed the data, with inputs from DWH and 475 ML; MM led the writing of the manuscript. All authors contributed critically to the drafts and gave 476 final approval for publication.

\section{7}

\section{References}

479 Almeida-Neto, M., Guimarães, P., Guimarães Jr, P. R., Loyola, R. D. \& Ulrich, W. (2008). A 480 consistent metric for nestedness analysis in ecological systems: reconciling concept and $481 \quad$ measurement. Oikos 117: 1227-1239.

482 Ashcroft, M. B., Chisholm, L. A. \& French, K. O. (2009). Climate change at the landscape scale: 483 Predicting fine-grained spatial heterogeneity in warming and potential refugia for vegetation. Global Change Biology 15: 656-667.

485 Austin, M. P. \& Van Niel, K. P. (2011). Improving species distribution models for climate change $486 \quad$ studies: Variable selection and scale. Journal of Biogeography 38: 1-8.

487 Bang, C., Sabo, J. L. \& Faeth, S. H. (2010). Reduced wind speed improves plant growth in a $488 \quad$ desert city. PloS One 5: e11061.

489 Barton, B. T. (2017). Beyond global warming: Putting the "climate" back into "climate change 490 ecology". Food Webs 13: 51-52.

491 Baselga, A. \& Orme, C. D. L. (2012). betapart: An R package for the study of beta diversity. $492 \quad$ Methods in Ecology and Evolution 3: 808-812.

493 Baselga, A., Orme, D., Villeger, S., De Bortoli, J. \& Leprieur, F. (2018). betapart: Partitioning 494 beta diversity into turnover and nestedness components. $R$ package version 1.5.1.

495 Behie, A. M., Kutz, S. \& Pavelka, M. S. (2014). Cascading effects of climate change: Do 496 hurricane-damaged forests increase risk of exposure to parasites? Biotropica 46: 25-31.

497 Bennie, J., Huntley, B., Wiltshire, A., Hill, M. O. \& Baxter, R. (2008). Slope, aspect and climate: 498 Spatially explicit and implicit models of topographic microclimate in chalk grassland. $499 \quad$ Ecological Modelling 216: 47-59.

500 Bertiller, M. B., Zaixso, P., Irisarri, M. \& Brevedan, E. R. (1996). The establishment of Festuca 501 pallescens in arid grasslands in Patagonia (Argentina): The effect of soil water stress. Journal of Arid Environments 32: 161-171. 
503

504

505

506 Bjorkman, A. D., Myers-Smith, I. H., Elmendorf, S. C., Normand, S., Rüger, N., Beck, P. S. A.,

507

508

509

510

511

512

513

514

515

516

517

518

519

520

521

522

523

524

525

526

527

528

529

530

531

532

533

534

Bintanja, R., Severijns, C., Haarsma, R. \& Hazeleger, W. (2014). The future of Antarctica's surface winds simulated by a high-resolution global climate model: 2. Drivers of 21st century changes. Journal of Geophysical Research: Atmospheres 119: 7160-7178.

Blach-Overgaard, A., Blok, D., Cornelissen, J. H. C., Forbes, B. C., Georges, D., Goetz, S. J., Guay, K. C., Henry, G. H. R., HilleRisLambers, J., Hollister, R. D., Karger, D. N., Kattge, J., Manning, P., Prevéy, J. S., Rixen, C., Schaepman-Strub, G., Thomas, H. J. D., Vellend, M., Wilmking, M., Wipf, S., Carbognani, M., Hermanutz, L., Lévesque, E., Molau, U., Petraglia, A., Soudzilovskaia, N. A., Spasojevic, M. J., Tomaselli, M., Vowles, T., Alatalo, J. M., Alexander, H. D., Anadon-Rosell, A., Angers-Blondin, S., Beest, M. t., Berner, L., Björk, R. G., Buchwal, A., Buras, A., Christie, K., Cooper, E. J., Dullinger, S., Elberling, B., Eskelinen, A., Frei, E. R., Grau, O., Grogan, P., Hallinger, M., Harper, K. A., Heijmans, M. M. P. D., Hudson, J., Hülber, K., Iturrate-Garcia, M., Iversen, C. M., Jaroszynska, F., Johnstone, J. F., Jørgensen, R. H., Kaarlejärvi, E., Klady, R., Kuleza, S., Kulonen, A., Lamarque, L. J., Lantz, T., Little, C. J., Speed, J. D. M., Michelsen, A., Milbau, A., Nabe-Nielsen, J., Nielsen, S. S., Ninot, J. M., Oberbauer, S. F., Olofsson, J., Onipchenko, V. G., Rumpf, S. B., Semenchuk, P., Shetti, R., Collier, L. S., Street, L. E., Suding, K. N., Tape, K. D., Trant, A., Treier, U. A., Tremblay, J.-P., Tremblay, M., Venn, S., Weijers, S., Zamin, T., Boulanger-Lapointe, N., Gould, W. A., Hik, D. S., Hofgaard, A., Jónsdóttir, I. S., Jorgenson, J., Klein, J., Magnusson, B., et al. (2018). Plant functional trait change across a warming tundra biome. Nature 562: 57-62.

Boelhouwers, J. C., Meiklejohn, K. I., Holness, S. D. \& Hedding, D. W. 2008. Geology, geomorphology and climate change. In: Chown, S. L. \& Froneman, P. W. (eds.) The Prince Edward Islands: Land-sea interactions in a changing ecosystem. Stellenbosch: SUN PRESS.

Böhner, J. \& Antonić, O. 2009. Land-surface parameters specific to topo-climatology. In: Hengl, T. \& Reuter, H. I. (eds.) Geomorphology: Concepts, software, applications. Elsevier.

Bovik, A. C. 2009. Basic gray level image processing. In: Bovik, A. C. (ed.) The Essential Guide to Image Processing. Boston: Academic Press.

Breedt, H. J., Craig, K. J. \& Jothiprakasam, V. D. (2018). Monin-Obukhov similarity theory and its application to wind flow modelling over complex terrain. Journal of Wind Engineering and Industrial Aerodynamics 182: 308-321. 
535 Burke, I. C., Reiners, W. A. \& Olson, R. K. (1989). Topographic control of vegetation in a mountain big sagebrush steppe. Vegetatio 84: 77-86.

537 Carl, G., Levin, S. C. \& Kühn, I. (2018). Spind: An R package to account for spatial 538 autocorrelation in the analysis of lattice data. Biodiversity Data Journal 6: e20760.

539 Cherry, M. \& Barton, B. (2017). Effects of wind on predator-prey interactions. Food Webs 13: $92-$ 540 97.

541 Chiras, D. 2017. Power from the wind: A practical guide to small-scale energy production. 542 Vancouver: New Society Publishers.

543 Cindori, M., Juretić, F., Kozmar, H. \& Džijan, I. (2018). Steady RANS model of the homogeneous 544 atmospheric boundary layer. Journal of Wind Engineering and Industrial Aerodynamics 173: $289-301$.

546 Combes, V. \& Matano, R. P. (2018). The Patagonian shelf circulation: Drivers and variability. Progress in Oceanography 167: 24-43.

548 Combrinck, M. L., Harms, T. M., McGeoch, M. A., Schoombie, J. \& le Roux, P. C. (2020). Wind 549 and seed: a conceptual model of shape-formation in the cushion plant Azorella selago. Plant and Soil.

551 Conrad, O., Bechtel, B., Bock, M., Dietrich, H., Fischer, E., Gerlitz, L., Wehberg, J., Wichmann, 552 V. \& Böhner, J. (2015). System for Automated Geoscientific Analyses (SAGA) v. 2.1.4. Geoscientific Model Development 8: 1991-2007.

554 Dadic, R., Mott, R., Lehning, M. \& Burlando, P. (2010). Wind influence on snow depth 555 distribution and accumulation over glaciers. Journal of Geophysical Research: Earth $556 \quad$ Surface $\mathbf{1 1 5}$.

557 Dahinden, F., Fischer, E. M. \& Knutti, R. (2017). Future local climate unlike currently observed 558 anywhere. Environmental Research Letters 12: 084004.

559 de Langre, E. (2008). Effects of wind on plants. Annual Review of Fluid Mechanics 40: 141-168.

560 Department of Rural Development and Land Reform (DRDLR), 2019: 1m Digital Elevation 561 Model - Marion Island, Directorate: National Geo-spatial Information, Department of 562 Rural Development and Land Reform, Republic of South Africa.

563 Fahnestock, J. T., Povirk, K. L. \& Welker, J. M. (2000). Ecological significance of litter 564 redistribution by wind and snow in arctic landscapes. Ecography 23: 623-631.

565 Fernández-Palacios, J. M. \& Nicolás, J. P. (1995). Altitudinal pattern of vegetation variation on 566 Tenerife. Journal of Vegetation Science 6: 183-190. 
567 Filibeck, G., Sperandii, M. G., Bazzichetto, M., Mancini, L. D., Rossini, F. \& Cancellieri, L. (2019). Exploring the drivers of vascular plant richness at very fine spatial scale in subMediterranean limestone grasslands (Central Apennines, Italy). Biodiversity and $570 \quad$ Conservation 28: 2701-2725.

571 Fitzgerald, N. B. \& Kirkpatrick, J. B. (2017). Wind distortion in alpine and Subantarctic plants is 572 constant among life forms but does not necessarily reflect prevailing wind direction. 573 Arctic, Antarctic, and Alpine Research 49: 521-535.

574 Freeman, B. G., Scholer, M. N., Ruiz-Gutierrez, V. \& Fitzpatrick, J. W. (2018). Climate change 575 causes upslope shifts and mountaintop extirpations in a tropical bird community. $576 \quad$ Proceedings of the National Academy of Sciences 115: 11982.

577 Friedman, J., Hastie, T. \& Tibshirani, R. (2000). Additive logistic regression: A statistical view of 578 boosting The Annals of Statistics 28: 337-407.

579 Friedman, J. H. (2001). Greedy function approximation: A gradient boosting machine. The Annals 580 of Statistics 29: 1189-1232.

581 Gandin, A., Gutjahr, S., Dizengremel, P. \& Lapointe, L. (2011). Source-sink imbalance increases 582 with growth temperature in the spring geophyte Erythronium americanum. Journal of Experimental Botany 62: 3467-3479.

584 Gardiner, B., Berry, P. \& Moulia, B. (2016). Review: Wind impacts on plant growth, mechanics and damage. Plant Science 245: 94-118.

586 Gardner, A. S., Maclean, I. M. D. \& Gaston, K. J. (2019). Climatic predictors of species 587 distributions neglect biophysiologically meaningful variables. Diversity and Distributions 588 25: $1318-1333$.

589 Gleason, H. A. (1939). The individualistic concept of the plant association. The American Midland $590 \quad$ Naturalist 21: 92-110.

591 Gómez-Ruiz, E. P. \& Lacher Jr, T. E. (2019). Climate change, range shifts, and the disruption of a 592 pollinator-plant complex. Scientific Reports 9: 14048.

593 Grace, J. 1977. Plant Response to Wind. London: Academic Press.

594 Gremmen, N. J. M., Chown, S. L. \& Marshall, D. J. (1998). Impact of the introduced grass 595 Agrostis stolonifera on vegetation and soil fauna communities at Marion Island, sub596 Antarctic. Biological Conservation 85: 223-231. 
597 Hadley, J. L. \& Smith, W. K. (1983). Influence of wind exposure on needle desiccation and mortality for timberline conifers in Wyoming, U.S.A. Arctic and Alpine Research 15: 127135.

600 Hadley, J. L. \& Smith, W. K. (1986). Wind effects on needles of timberline conifers: Seasonal 601 influence on mortality. Ecology 67: 12-19.

602 Hedding, D. W., Nel, W. \& Anderson, R. L. (2015). Aeolian processes and landforms in the sub$603 \quad$ Antarctic: preliminary observations from Marion Island. Polar Research 34: 26365.

604 Hendershot, W. H., Lalande, H. \& Duquette, H. 2008. Soil reaction and exchangeable acidity. In: 605 Carter, M. R. \& Gregorich, E. G. (eds.) Soil sampling and methods of analysis. 2 ed. Boca 606 Raton: CRC Press.

607 Holtmeier, F.-K. \& Broll, G. (2010). Wind as an ecological agent at treelines in North America, 608 the Alps, and the European subarctic. Physical Geography 31: 203-233.

609 Jeong, D. I. \& Sushama, L. (2019). Projected changes to mean and extreme surface wind speeds 610 for North America based on regional climate model simulations. Atmosphere 10: 497.

611 Kardol, P., Campany, C. E., Souza, L., Norby, R. J., Weltzin, J. F. \& Classen, A. T. (2010). 612 Climate change effects on plant biomass alter dominance patterns and community 613 evenness in an experimental old-field ecosystem. Global Change Biology 16: 2676-2687.

614 Katsaprakakis, D. A. \& Christakis, D. G. 2012. Wind parks design, including representative case 615 studies. In: Sayigh, A. (ed.) Comprehensive Renewable Energy. Oxford: Elsevier.

616 Kemppinen, J., Niittynen, P., Aalto, J., Roux, P. C. 1. \& Luoto, M. (2019). Water as a resource, 617 stress and disturbance shaping tundra vegetation. Oikos 128: 811-822.

618 Kirkpatrick, J. B., Bridle, K. L. \& Lynch, A. J. J. (2002). Changes in alpine vegetation related to 619 geomorphological processes and climatic change on Hill One, Southern Range, Tasmania, $620 \quad 1989$ - 2000. Australian Journal of Botany 50: 753-759.

621 Kling, M. M. \& Ackerly, D. D. (2020). Global wind patterns and the vulnerability of wind622 dispersed species to climate change. Nature Climate Change 10: 868-875.

623 Kolstad, E. W. \& Johansson, K. A. (2011). Uncertainties associated with quantifying climate 624 change impacts on human health: A case study for diarrhea. Environmental Health 625 Perspectives 119: 299-305.

626 Kullman, L. \& Loyer, N. (2005). Wind-conditioned 20th century decline of Birch treeline 627 vegetation in the Swedish Scandes. Arctic 58: 286-294. 
Lahav, E. \& Zamet, D. (1999). Flowers, fruitlets and fruit drop in avocado trees Revista Chapingo Serie Horticultura 5: 95-100.

630 le Roux, P. C. 2008. Climate and climate change. In: Chown, S. L. \& Froneman, P. W. (eds.) The

631 Prince Edward Islands: Land-sea interactions in a changing ecosystem. Stellenbosch: 632 SUN PRESS.

633 le Roux, P. C., Aalto, J. \& Luoto, M. (2013a). Soil moisture's underestimated role in climate 634 change impact modelling in low-energy systems. Global Change Biology 19: 2965-2975.

635 le Roux, P. C., Lenoir, J., Pellissier, L., Wisz, M. S. \& Luoto, M. (2013b). Horizontal, but not 636 vertical, biotic interactions affect fine-scale plant distribution patterns in a low-energy $637 \quad$ system. Ecology 94: 671-682.

638 le Roux, P. C. \& Luoto, M. (2014). Earth surface processes drive the richness, composition and 639 occurrence of plant species in an arctic-alpine environment. Journal of Vegetation Science 25: $45-54$

641 le Roux, P. C. \& McGeoch, M. A. (2010). Interaction intensity and importance along two stress 642 gradients: Adding shape to the stress-gradient hypothesis. Oecologia 162: 733-745.

643 Lenoir, J., Gégout, J.-C., Guisan, A., Vittoz, P., Wohlgemuth, T., Zimmermann, N. E., Dullinger, 644 S., Pauli, H., Willner, W. \& Svenning, J.-C. (2010). Going against the flow: Potential mechanisms for unexpected downslope range shifts in a warming climate. Ecography 33: 295-303.

647 Liu, H., Mi, Z., Lin, L., Wang, Y., Zhang, Z., Zhang, F., Wang, H., Liu, L., Zhu, B., Cao, G., 648 Zhao, X., Sanders, N. J., Classen, A. T., Reich, P. B. \& He, J.-S. (2018). Shifting plant 649 species composition in response to climate change stabilizes grassland primary production. 650 Proceedings of the National Academy of Sciences 115: 4051.

651 Liu, Y.-H., Offler, C. \& Ruan, Y.-L. (2013). Regulation of fruit and seed response to heat and 652 drought by sugars as nutrients and signals. Frontiers in Plant Science 4: 282.

653 Lönnell, N., Norros, V., Sundberg, S., Rannik, Ü., Johansson, V., Ovaskainen, O. \& Hylander, K. 654 (2015). Testing a mechanistic dispersal model against a dispersal experiment with a wind655 dispersed moss. Oikos 124: 1232-1240.

656 Lugo, A. E. (2008). Visible and invisible effects of hurricanes on forest ecosystems: An 657 international review. Austral Ecology 33: 368-398.

658 Lynch, A. J. J. \& Kirkpatrick, J. B. (1995). Pattern and process in alpine vegetation and landforms at Hill One, Southern Range, Tasmania. Australian Journal of Botany 43: 537-554. 
660 Maclean, I. M. D. (2020). Predicting future climate at high spatial and temporal resolution. Global Change Biology 26: 1003-1011.

662 Mau, A. C., Reed, S. C., Wood, T. E. \& Cavaleri, M. A. (2018). Temperate and tropical forest

663

664

665

666

667

668

669 McGlone, M. S. (2002). The Late Quaternary peat, vegetation and climate history of the Southern 670

671

682 683 684 685 of fine-scale variation in plant communities. Dryad Dataset, 686 687 688 689 690 canopies are already functioning beyond their thermal thresholds for photosynthesis. Forests 9: 47.

McCune, B. (2007). Improved estimates of incident radiation and heat load using non-parametric regression against topographic variables. Journal of Vegetation Science 18: 751-754.

McCune, B. \& Keon, D. (2002). Equations for potential annual direct incident radiation and heat load. Journal of Vegetation Science 13: 603-606. Oceanic Islands of New Zealand. Quaternary Science Reviews 21: 683-707.

McIntire, E. J. B., Piper, F. I. \& Fajardo, A. (2016). Wind exposure and light exposure, more than elevation-related temperature, limit tree line seedling abundance on three continents. Journal of Ecology 104: 1379-1390.

Menéndez, R., Megías, A. G., Hill, J. K., Braschler, B., Willis, S. G., Collingham, Y., Fox, R., Roy, D. B. \& Thomas, C. D. (2006). Species richness changes lag behind climate change. Proceedings of the Royal Society B: Biological Sciences 273: 1465-1470.

Mitchell, S. J. (2012). Wind as a natural disturbance agent in forests: a synthesis. Forestry: An International Journal of Forest Research 86: 147-157.

Mod, H. K., Scherrer, D., Luoto, M., Guisan, A. \& Scheiner, S. (2016). What we use is not what we know: environmental predictors in plant distribution models. Journal of Vegetation Science 27: 1308-1322.

Møller, A. P. (2013). Long-term trends in wind speed, insect abundance and ecology of an insectivorous bird. Ecosphere 4: art6.

4 Momberg, M., Hedding, D. W., Luoto, M., le Roux, P. C. (2021). Exposing wind stress as a driver 86 https://doi.org/10.5061/dryad.547d7wm7k.

87 Morueta-Holme, N., Engemann, K., Sandoval-Acuña, P., Jonas, J. D., Segnitz, R. M. \& Svenning, J.-C. (2015). Strong upslope shifts in Chimborazo's vegetation over two centuries since Humboldt. Proceedings of the National Academy of Sciences 112: 12741.

Müller, M. 2012. Generalized linear models. Handbook of Computational Statistics. Springer. 
691 Niittynen, P., Heikkinen, R., Aalto, J., Guisan, A., Kemppinen, J. \& Luoto, M. (2020a). Fine-scale tundra vegetation patterns are strongly related to winter thermal conditions. Nature Climate Change.

694 Niittynen, P., Heikkinen, R. \& Luoto, M. (2020b). Decreasing snow cover alters functional 695 composition and diversity of Arctic tundra. Proceedings of the National Academy of $696 \quad$ Sciences 117: 202001254.

697 Niittynen, P., Heikkinen, R. K. \& Luoto, M. (2018). Snow cover is a neglected driver of Arctic $698 \quad$ biodiversity loss. Nature Climate Change 8: 997-1001.

699 Niittynen, P. \& Luoto, M. (2018). The importance of snow in species distribution models of arctic $700 \quad$ vegetation. Ecography 41: 1024-1037.

701 Nyberg, J., Malmgren, B. A., Winter, A., Jury, M. R., Kilbourne, K. H. \& Quinn, T. M. (2007). 702 Low Atlantic hurricane activity in the 1970s and 1980s compared to the past 270 years. $703 \quad$ Nature 447: 698-701.

704 Nylén, T., Hellemaa, P. \& Luoto, M. (2015). Determinants of sediment properties and organic 705 matter in beach and dune environments based on boosted regression trees. Earth Surface $706 \quad$ Processes and Landforms 40: 1137-1145.

707 Nylén, T. \& Luoto, M. (2015). Influence of patch size and connectivity on beach and dune species 708 in land-uplift coasts. Plant Ecology \& Diversity 9: 35-44.

709 Okitsu, S. \& Ito, K. (1984). Vegetation dynamics of the Siberian dwarf pine (Pinus pumila Regel) 710 in the Taisetsu mountain range, Hokkaido, Japan. Vegetatio 58: 105-113.

711 Oksanen, J., Blanchet, F. G., Friendly, M., Kindt, R., Legendre, P., McGlinn, D., Minchin, P. R., 712 O'Hara, R. B., Simpson, G. L., Solymos, P., Stevens, M. H. H., Szoecs, E. \& Wagner, H. 713 (2018). vegan: Community Ecology Package. $R$ package version 2.5-2 https://CRAN.R714 project.org/package $=$ vegan.

715 Onoda, Y. \& Anten, N. P. R. (2011). Challenges to understand plant responses to wind. Plant $716 \quad$ Signaling \& Behavior 6: 1057-1059.

717 Pammenter, N. W., Drennan, P. M. \& Smith, V. R. (1986). Physiological and anatomical aspects 718 of photosynthesis of two Agrostis species at a sub-Antarctic island. New Phytologist 102: $719 \quad 143-160$.

720 Parmesan, C. \& Hanley, M. E. (2015). Plants and climate change: Complexities and surprises. 721 Annals of Botany 116: 849-864. 

Colwell, R. K., Danielsen, F., Evengård, B., Falconi, L., Ferrier, S., Frusher, S., Garcia, R. A., Griffis, R. B., Hobday, A. J., Janion-Scheepers, C., Jarzyna, M. A., Jennings, S., Lenoir, J., Linnetved, H. I., Martin, V. Y., McCormack, P. C., McDonald, J., Mitchell, N. J., Mustonen, T., Pandolfi, J. M., Pettorelli, N., Popova, E., Robinson, S. A., Scheffers, B. R., Shaw, J. D., Sorte, C. J. B., Strugnell, J. M., Sunday, J. M., Tuanmu, M.-N., Vergés, A., Villanueva, C., Wernberg, T., Wapstra, E. \& Williams, S. E. (2017). Biodiversity 729 redistribution under climate change: Impacts on ecosystems and human well-being.

731 Pendlebury, S. \& Barnes-Keoghan, I. (2007). Climate and climate change in the sub-Antarctic. Papers and Proceedings of the Royal Society of Tasmania 141: 67-81.

733 R Core Team 2018. R: A language and environment for statistical computing. Vienna, Austria: R Foundation for Statistical Computing.

735 Radchuk, V., Reed, T., Teplitsky, C., van de Pol, M., Charmantier, A., Hassall, C., Adamík, P., 736 Adriaensen, F., Ahola, M. P., Arcese, P., Miguel Avilés, J., Balbontin, J., Berg, K. S., Borras, A., Burthe, S., Clobert, J., Dehnhard, N., de Lope, F., Dhondt, A. A., Dingemanse, N. J., Doi, H., Eeva, T., Fickel, J., Filella, I., Fossøy, F., Goodenough, A. E., Hall, S. J. G., Hansson, B., Harris, M., Hasselquist, D., Hickler, T., Joshi, J., Kharouba, H., Martínez, J. G., Mihoub, J.-B., Mills, J. A., Molina-Morales, M., Moksnes, A., Ozgul, A., Parejo, D., Pilard, P., Poisbleau, M., Rousset, F., Rödel, M.-O., Scott, D., Senar, J. C., Stefanescu, C., Stokke, B. G., Kusano, T., Tarka, M., Tarwater, C. E., Thonicke, K., Thorley, J., Wilting, A., Tryjanowski, P., Merilä, J., Sheldon, B. C., Pape Møller, A., Matthysen, E., Janzen, F., Dobson, F. S., Visser, M. E., Beissinger, S. R., Courtiol, A. \& Kramer-Schadt, S. (2019). Adaptive responses of animals to climate change are most likely insufficient. Nature Communications 10: 3109.

Smith, V. R. \& Steenkamp, M. (2001). Classification of the terrestrial habitats on Marion Island 749 Smith, V. R., Steenkamp, M. \& Gremmen, N. J. M. (2001). Terrestrial habitats on sub-Antarctic 750 751 Marion Island: Their vegetation, edaphic attributes, distribution and response to climate change. South African Journal of Botany 67: 641-654. 
773 Thomas, H. J. D., Bjorkman, A. D., Myers-Smith, I. H., Elmendorf, S. C., Kattge, J., Diaz, S., 774 775

Song, Y.-B., Hu, Y.-K., Pan, X., Liu, G.-F., Xiong, W., Dong, M. \& Cornelissen, J. H. C. (2020) Association of leaf silicon content with chronic wind exposure across and within herbaceous plant species. Global Ecology and Biogeography 29: 711-721.

Sparacino, J., Renison, D., Devegili, A. M. \& Suarez, R. (2020). Wind protection rather than soil water availability contributes to the restriction of high-mountain forest to ravines. New Forests 51: 101-117.

Sturm, M., Liston, G. E., Benson, C. S. \& Holmgren, J. (2001). Characteristics and growth of a snowdrift in Arctic Alaska, U.S.A. Arctic, Antarctic, and Alpine Research 33: 319-329.

Sun, S.-S., Liu, X.-P., He, Y.-H., Wei, S.-L., Zhang, L.-M., Lv, P., Bao, C., Wang, M.-M. \& Cheng, L. (2019). Responses of annual herb plant community characteristics to increased precipitation and reduced wind velocity in semiarid sandy grassland. Ecology and Evolution 0: 1-11.

Sutherland, W. J., Barnard, P., Broad, S., Clout, M., Connor, B., Côté, I. M., Dicks, L. V., Doran, H., Entwistle, A. C., Fleishman, E., Fox, M., Gaston, K. J., Gibbons, D. W., Jiang, Z., Keim, B., Lickorish, F. A., Markillie, P., Monk, K. A., Pearce-Higgins, J. W., Peck, L. S., Pretty, J., Spalding, M. D., Tonneijck, F. H., Wintle, B. C. \& Ockendon, N. (2017). A 2017 horizon scan of emerging issues for global conservation and biological diversity. Trends in Ecology \& Evolution 32: 31-40.

Thom, D. \& Seidl, R. (2016). Natural disturbance impacts on ecosystem services and biodiversity in temperate and boreal forests. Biological Reviews of the Cambridge Philosophical Society 91: 760-781. Vellend, M., Blok, D., Cornelissen, J. H. C., Forbes, B. C., Henry, G. H. R., Hollister, R. D., Normand, S., Prevéy, J. S., Rixen, C., Schaepman-Strub, G., Wilmking, M., Wipf, S., Cornwell, W. K., Beck, P. S. A., Georges, D., Goetz, S. J., Guay, K. C., Rüger, N., Soudzilovskaia, N. A., Spasojevic, M. J., Alatalo, J. M., Alexander, H. D., Anadon-Rosell, A., Angers-Blondin, S., te Beest, M., Berner, L. T., Björk, R. G., Buchwal, A., Buras, A., Carbognani, M., Christie, K. S., Collier, L. S., Cooper, E. J., Elberling, B., Eskelinen, A., Frei, E. R., Grau, O., Grogan, P., Hallinger, M., Heijmans, M. M. P. D., Hermanutz, L., Hudson, J. M. G., Johnstone, J. F., Hülber, K., Iturrate-Garcia, M., Iversen, C. M., Jaroszynska, F., Kaarlejarvi, E., Kulonen, A., Lamarque, L. J., Lantz, T. C., Lévesque, E., Little, C. J., Michelsen, A., Milbau, A., Nabe-Nielsen, J., Nielsen, S. S., Ninot, J. M., 
792

793

794

795

796

797

798

799 Vonlanthen, C., Bühler, A., Veit, H., Kammer, P. \& Eugster, W. (2006a). Alpine plant 800

801

802 803

804

805

806

807 Whitehead, F. H. (1954). A study of the relation between growth form and exposure on Monte communities: A statistical assessment of their relation to microclimatological, pedological, geomorphological, and other factors. Physical Geography 27: 137-154.

808

809 Maiella, Italy. Journal of Ecology 42: 180-186.

Whitehead, F. H. (1959). Vegetational changes in response to alterations of surface roughness on M. Maiella, Italy. Journal of Ecology 47: 603-606.

Williams, J. W. \& Jackson, S. T. (2007). Novel climates, no-analog communities, and ecological surprises. Frontiers in Ecology and the Environment 5: 475-482.

Williams, R. J. \& Ashton, D. H. (1987). The composition, structure and distribution of heathland and grassland communities in the subalpine tract of the Bogong High Plains, Victoria. Australian Journal of Ecology 12: 57-71. 

47: 415-427.

818 Wood, S. N. 2006. Generalized Additive Models: An Introduction with R. Boca Raton: Chapman and Hall.

820 Wood, S. N. \& Augustin, N. H. (2002). GAMs with integrated model selection using penalized 821 regression splines and applications to environmental modelling. Ecological Modelling 157: $822 \quad 157-177$.

823 Xuan, Z. \& Chang, N.-B. (2014). Modeling the climate-induced changes of lake ecosystem 824 structure under the cascade impacts of hurricanes and droughts. Ecological Modelling 288:

825 79-93.

826 Yang, M., Défossez, P., Danjon, F. \& Fourcaud, T. (2014). Tree stability under wind: Simulating 827 uprooting with root breakage using a finite element method. Annals of Botany 114: 695828709.

829 Young, I. R. \& Ribal, A. (2019). Multiplatform evaluation of global trends in wind speed and $830 \quad$ wave height. Science 364: 548.

831 Young, I. R., Zieger, S. \& Babanin, A. V. (2011). Global trends in wind speed and wave height. 832 Science 332: 451.

833 Zeng, Z., Ziegler, A. D., Searchinger, T., Yang, L., Chen, A., Ju, K., Piao, S., Li, L. Z. X., Ciais, 834 P., Chen, D., Liu, J., Azorin-Molina, C., Chappell, A., Medvigy, D. \& Wood, E. F. (2019). 835 A reversal in global terrestrial stilling and its implications for wind energy production.

837 Zhang, X., Zhang, B., Feeley, K. J., Wang, G. G., Zhang, J. \& Zhai, L. (2019). Ecological 838 contingency in species shifts: downslope shifts of woody species under warming climate 839 and land-use change. Environmental Research Letters 14: 114033.

840 Zhang, Y., Liu, C., Tang, Y. \& Yang, Y. (2007). Trends in pan evaporation and reference and 841 actual evapotranspiration across the Tibetan Plateau. Journal of Geophysical Research: $842 \quad$ Atmospheres 112.

843 Zheng, M., Song, J., Ru, J., Zhou, Z., Zhong, M., Jiang, L., Hui, D. \& Wan, S. (2020). Effects of 844 grazing, wind erosion, and dust deposition on plant community composition and structure in a temperate steppe. Ecosystems. 
869 Table 1 A summary of key papers highlighting the types of research questions that have been examined, 870 and illustrating broadly the currently knowledge in this field.

\begin{tabular}{|c|c|c|c|c|c|}
\hline & $\begin{array}{l}\text { Study } \\
\text { location }\end{array}$ & Ecosystem & $\begin{array}{l}\text { Spatial } \\
\text { scale }\end{array}$ & Result & Reference \\
\hline Richness & $\begin{array}{l}\text { Mongolia, } \\
\text { China }\end{array}$ & $\begin{array}{l}\text { Semi-arid } \\
\text { temperate } \\
\text { steppe }\end{array}$ & $\begin{array}{l}4 \times 4 \mathrm{~m} \\
\text { plots }\end{array}$ & $\begin{array}{l}\text { Wind erosion did not affect species } \\
\text { richness, while dust deposition (due to } \\
\text { wind erosion) reduced species richness. }\end{array}$ & $\begin{array}{l}\text { Zheng et al. } \\
\text { (2020) }\end{array}$ \\
\hline on cover & $\begin{array}{l}\text { Hill One, } \\
\text { Southern } \\
\text { range, } \\
\text { Tasmania }\end{array}$ & Alpine & $\begin{array}{l}1.5 \times 1.0 \mathrm{~m} \\
\text { plots }\end{array}$ & $\begin{array}{l}\text { Vegetation cover decreased over } 11 \text { years, } \\
\text { mostly due to erosion, caused by an } \\
\text { increase in wind speed. }\end{array}$ & $\begin{array}{l}\text { Kirkpatrick } \\
\text { et al. (2002) }\end{array}$ \\
\hline & $\begin{array}{l}\text { Sonoran } \\
\text { Desert, } \\
\text { Arizona, } \\
\text { USA }\end{array}$ & $\begin{array}{l}\text { Desert, } \\
\text { desert } \\
\text { remnants and } \\
\text { urban sites }\end{array}$ & $\begin{array}{l}20 \\
\text { individually } \\
\text { potted plants } \\
\text { at each site }\end{array}$ & $\begin{array}{l}\text { Reduced wind speed increased cover of } \\
\text { individuals in desert and desert remnants. } \\
\text { In urban sites reduced wind speed had no } \\
\text { effect on cover. }\end{array}$ & $\begin{array}{l}\text { Bang et al. } \\
(2010)\end{array}$ \\
\hline & $\begin{array}{l}\text { Mongolia, } \\
\text { China }\end{array}$ & $\begin{array}{l}\text { Semi-arid } \\
\text { temperate } \\
\text { steppe }\end{array}$ & $\begin{array}{l}4 \times 4 \mathrm{~m} \\
\text { plots }\end{array}$ & $\begin{array}{l}\text { Wind erosion decreased total plant cover. } \\
\text { Dust deposition by wind resulted in higher } \\
\text { vegetation cover. }\end{array}$ & $\begin{array}{l}\text { Zheng et al. } \\
\text { (2020) }\end{array}$ \\
\hline Composition & Swiss Alps & Alpine & $\begin{array}{l}1 \times 1 \mathrm{~m} \\
\text { plots }\end{array}$ & $\begin{array}{l}\text { Wind speed was an important driver of } \\
\text { species composition; } \mathrm{R}^{2}>0.35 \text {. }\end{array}$ & $\begin{array}{l}\text { Vonlanthen } \\
\text { et al. } \\
\text { (2006a) }\end{array}$ \\
\hline \multirow[t]{3}{*}{$\begin{array}{l}\text { Distribution of } \\
\text { vegetation types }\end{array}$} & $\begin{array}{l}\text { North } \\
\text { America, } \\
\text { the Alps, } \\
\text { European } \\
\text { subarctic }\end{array}$ & Alpine & Review & $\begin{array}{l}\text { Wind determines the treeline position in } \\
\text { three different ecosystems and can } \\
\text { override the role of heat deficiency. }\end{array}$ & $\begin{array}{l}\text { Holtmeier } \\
\text { and Broll } \\
(2010)\end{array}$ \\
\hline & $\begin{array}{l}\text { Swedish } \\
\text { Scandes }\end{array}$ & Alpine & $\begin{array}{l}10 \times 10 \mathrm{~m} \\
\text { plots }\end{array}$ & $\begin{array}{l}\text { Wind determines the birch treeline and } \\
\text { increasing wind circulation constrains } \\
\text { upslope treeline expansion in response to } \\
\text { warming temperatures. }\end{array}$ & $\begin{array}{l}\text { Kullman } \\
\text { and Loyer } \\
(2005)\end{array}$ \\
\hline & $\begin{array}{l}5 \text { mountain } \\
\text { regions } \\
\text { from } 3 \\
\text { continents }\end{array}$ & Alpine & $50 \mathrm{~m}^{2}$ plots & $\begin{array}{l}\text { Wind exposure was the main determinant } \\
\text { of the number of seedlings present at the } \\
\text { treeline, with increased wind exposure } \\
\text { correlated with fewer tree seedlings. }\end{array}$ & $\begin{array}{l}\text { McIntire et } \\
\text { al. (2016) }\end{array}$ \\
\hline
\end{tabular}




\begin{tabular}{|c|c|c|c|c|c|}
\hline & $\begin{array}{l}\text { Central } \\
\text { Argentina }\end{array}$ & $\begin{array}{l}\text { Forest } \\
\text { patches }\end{array}$ & $\begin{array}{l}396 \\
\text { individual } \\
\text { saplings }\end{array}$ & $\begin{array}{l}\text { Reduced wind speeds likely restrict the } \\
\text { occurrence of forest to ravines. }\end{array}$ & $\begin{array}{l}\text { Sparacino et } \\
\text { al. (2020) }\end{array}$ \\
\hline Review & $\begin{array}{l}\text { Multiple } \\
\text { locations }\end{array}$ & $\begin{array}{l}\text { Boreal \& } \\
\text { temperate } \\
\text { forest }\end{array}$ & & $\begin{array}{l}\text { A review of the impact of disturbance } \\
\text { agents on natural vegetation showed } 146 \\
\text { studies of wind as a disturbance agent } \\
\text { versus } 677 \text { for fire. More than } 87 \% \text { of } \\
\text { these studies are from Europe or North } \\
\text { America. There was no difference between } \\
\text { the effects of wind, fire and bark beetles } \\
\text { on biodiversity. }\end{array}$ & $\begin{array}{l}\text { Thom and } \\
\text { Seidl (2016) }\end{array}$ \\
\hline
\end{tabular}

871

This article is protected by copyright. All rights reserved 
Table 2 Vegetation and abiotic characteristics of each grid. See Fig. 1 for the location of the sampling grids. VWC: volumetric water content

\begin{tabular}{|c|c|c|c|c|c|c|c|c|c|c|c|}
\hline \multirow{2}{*}{ Grid } & \multirow{2}{*}{$\begin{array}{c}\text { Vascular plant } \\
\text { cover (mean; \%) }\end{array}$} & \multirow{2}{*}{$\begin{array}{l}\text { Total vascular } \\
\text { plant richness }\end{array}$} & \multicolumn{3}{|c|}{ Summer temperature $\left({ }^{\circ} \mathrm{C}\right)$} & \multicolumn{3}{|c|}{ Winter temperature $\left({ }^{\circ} \mathrm{C}\right)$} & \multirow{2}{*}{$\begin{array}{c}\text { Soil moisture } \\
\text { range }(\% \mathrm{VWC})\end{array}$} & \multicolumn{2}{|c|}{ Wind stress } \\
\hline & & & Minimum & Mean & Maximum & Minimum & Mean & Maximum & & $\begin{array}{c}\text { Mean } \\
\text { maximum }\end{array}$ & $\begin{array}{c}\text { Absolute } \\
\text { maximum }\end{array}$ \\
\hline 1 & 72 & 9 & 2.92 & 6.28 & 8.12 & 1.62 & 4.02 & 5.92 & 76.2 & 5.50 & 6.06 \\
\hline 2 & 65 & 15 & 2.91 & 6.35 & 7.71 & 2.66 & 4.70 & 6.46 & 41.2 & 6.52 & 7.02 \\
\hline 3 & 65 & 12 & 5.56 & 7.70 & 12.86 & 2.61 & 4.83 & 6.21 & 69.2 & 7.62 & 8.22 \\
\hline 4 & 55 & 12 & 2.72 & 5.77 & 11.22 & 2.19 & 4.10 & 5.49 & 68.6 & 8.22 & 8.53 \\
\hline 5 & 48 & 10 & 4.42 & 5.50 & 6.62 & 3.58 & 5.34 & 6.28 & 48.7 & 6.22 & 6.46 \\
\hline 6 & 67 & 9 & 4.24 & 6.12 & 10.54 & 2.48 & 4.81 & 6.48 & 38.7 & 6.10 & 6.60 \\
\hline 7 & 64 & 9 & 4.60 & 6.66 & 8.10 & 4.13 & 5.73 & 7.63 & 48.1 & 6.18 & 6.46 \\
\hline 8 & 25 & 11 & 3.83 & 5.02 & 6.33 & 0.00 & 1.06 & 2.45 & 27.6 & 7.18 & 7.64 \\
\hline 9 & 19 & 10 & 4.72 & 5.97 & 7.22 & 0.36 & 1.70 & 3.26 & 53.4 & 7.48 & 7.60 \\
\hline
\end{tabular}


Table 3 Model fit and variable importance for all variables when predicting spatial variation in species richness and vegetation cover in the full model. The five most important predictors for each approach are highlighted in bold and significant predictors are indicated with an asterisk. GAM = generalized additive model; GLZ = generalized linear model. See Table A2 for results from the generalized boosted regression models.

\begin{tabular}{|c|c|c|c|c|}
\hline & \multicolumn{2}{|c|}{ Richness } & \multicolumn{2}{|c|}{ Cover } \\
\hline & GAM & GLZ & GAM & GLZ \\
\hline Deviance explained & 24.9 & 19.5 & 67.7 & 66.9 \\
\hline & \multicolumn{4}{|c|}{ Relative importance (\%) } \\
\hline Rock cover & $16.7 *$ & $12.6 *$ & 94.15* & $94.63 *$ \\
\hline Wind stress: & 33.8* & 6.0 & 3.00* & 2.88* \\
\hline Soil pH & $19.4^{*}$ & $16.0 *$ & 0.04 & 0.06 \\
\hline Soil depth & $12.2 *$ & 13.8 & 0.17 & 0.21 \\
\hline $\begin{array}{c}\text { Temperature: } \\
\text { summer }\end{array}$ & 1.5 & 1.7 & $0.90 *$ & 0.12 \\
\hline Temperature: winter & $13.8 *$ & $44.5^{*}$ & 0.49 & 0.64 \\
\hline PDIR & 0.0 & 1.3 & $0.70 *$ & $0.52 *$ \\
\hline Soil moisture & 2.6 & 4.0 & $0.65^{*}$ & $0.94 *$ \\
\hline
\end{tabular}




\section{Figure legends}

Figure 1 Study site location on Marion Island and study design. a: Marion Island, with contour intervals of $150 \mathrm{~m}$ and study location indicated by the red block; b: the location of all 9 study grids (each $8 \times 20 \mathrm{~m}$; the distance from grid 1 to grid 9 is $\sim 900 \mathrm{~m}$; Google Earth imagery), with the Van den Boogaard river indicated in blue; c: biotic and abiotic data were sampled from 160 quadrats within each grid, resulting in a total of 1440 quadrats (each 1 x $1 \mathrm{~m}$ in size; indicated here with the white frame); d: drone imagery was obtained for each grid, from which a digital surface model was created and used to calculate the wind exposure of each quadrat; e: wind speed for each grid was obtained from a computational fluid dynamics model of island-scale wind speed; f: wind exposure (calculated from drone imagery products) and wind speed were combined to create a wind stress metric for each quadrat.

Figure 2 Variation in maximum wind stress in all nine study grids (see Fig. 1 for location of the grids) indicated for each $1 \mathrm{~m}^{2}$ quadrat. Cooler colours indicate low wind stress and warmer colours indicate higher wind stress.

Figure 3 Species richness across all nine study grids (see Fig. 1 for location of the grids), with vascular plant species richness indicated for each $1 \mathrm{~m}^{2}$ quadrat. Cooler colours indicate low species richness and warmer colours indicate higher richness. 
Figure 4 Individual predictor variables' response curves for species richness in GAM models. Tick marks on the $\mathrm{x}$-axis indicate observed values. Solid black lines represent the response curves from the simple model (excluding wind stress predictor variables), while dashed red lines represent the response curves from the full model.

Figure 5 Individual predictor variables' response curves for vegetation cover in GAM models.

Tick marks on the $\mathrm{x}$-axis indicate observed values. Solid black lines represent the response curves in the simple model (excluding wind stress predictor variables), while dashed red lines represent the response curves in the full model.

Figure 6 a) Non-metric multidimensional scaling (nMDS) ordination plot showing variables impact on species composition (Stress $=0.18$ ), symbols indicate sampled quadrats; $b$ ) Variable importance, as assessed by marginal $\mathrm{R}^{2}$ values, from the PERMANOVA. Temp = soil temperature. 


\section{Figures}

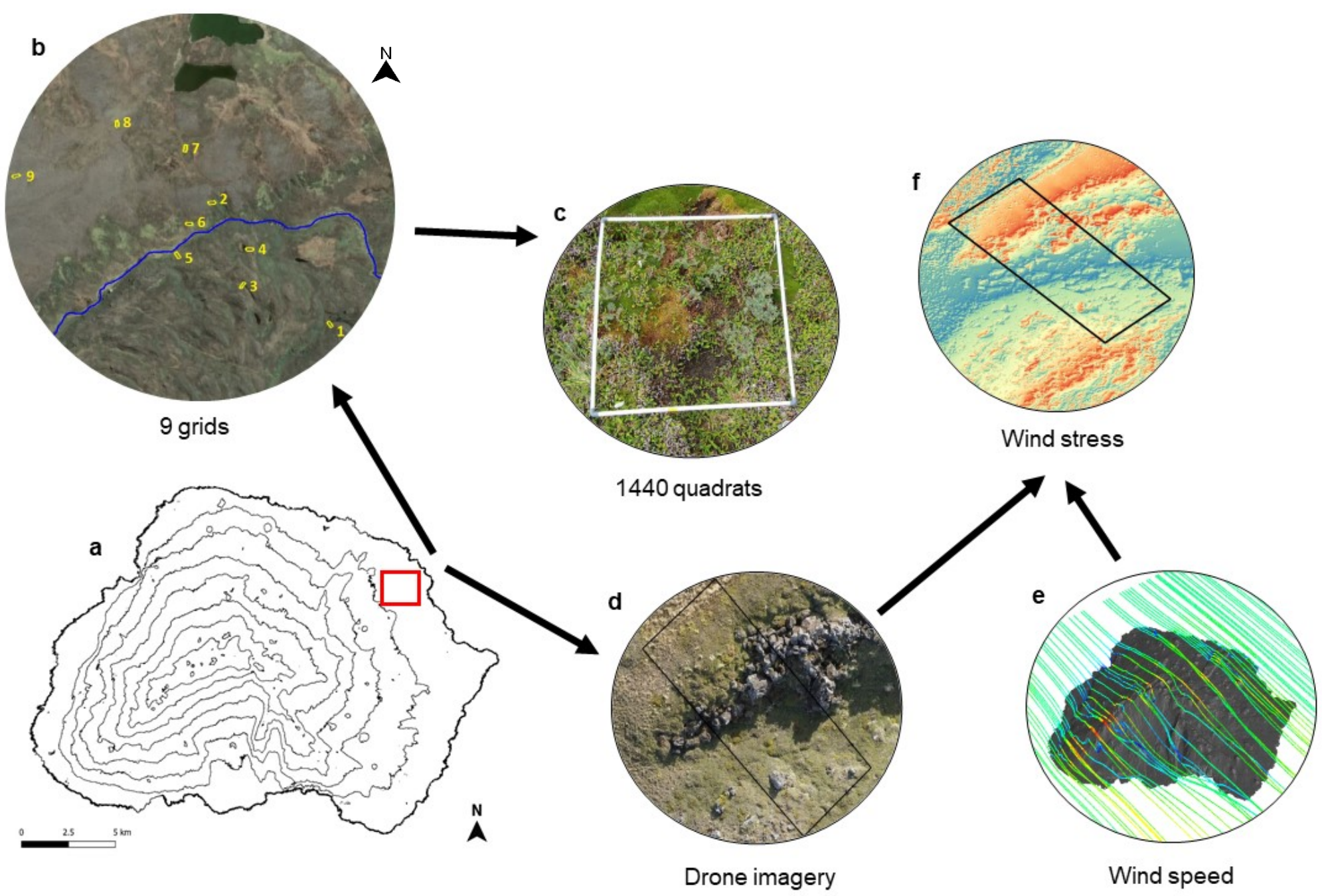

Figure 1

This article is protected by copyright. All rights reserved 

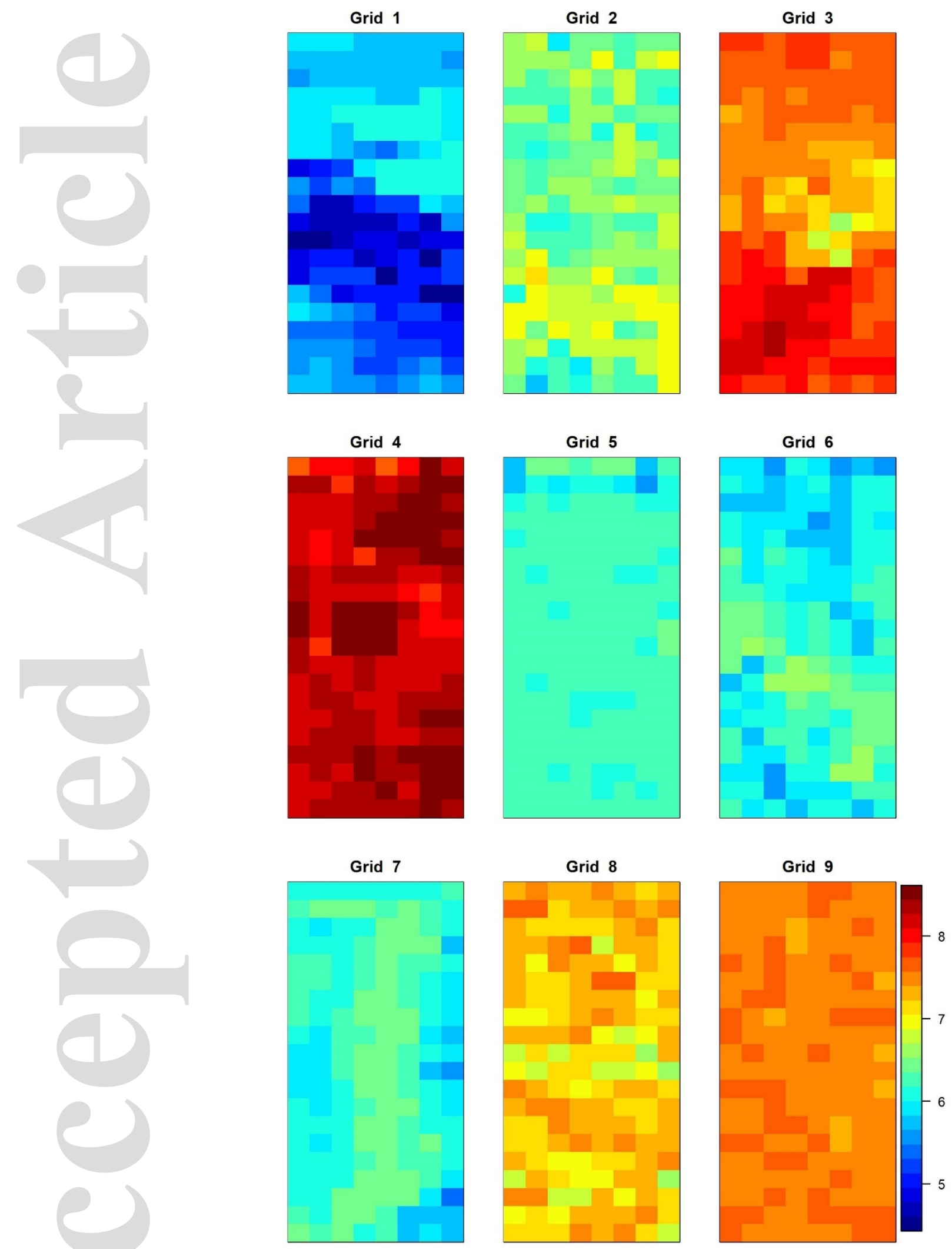

Figure 2 

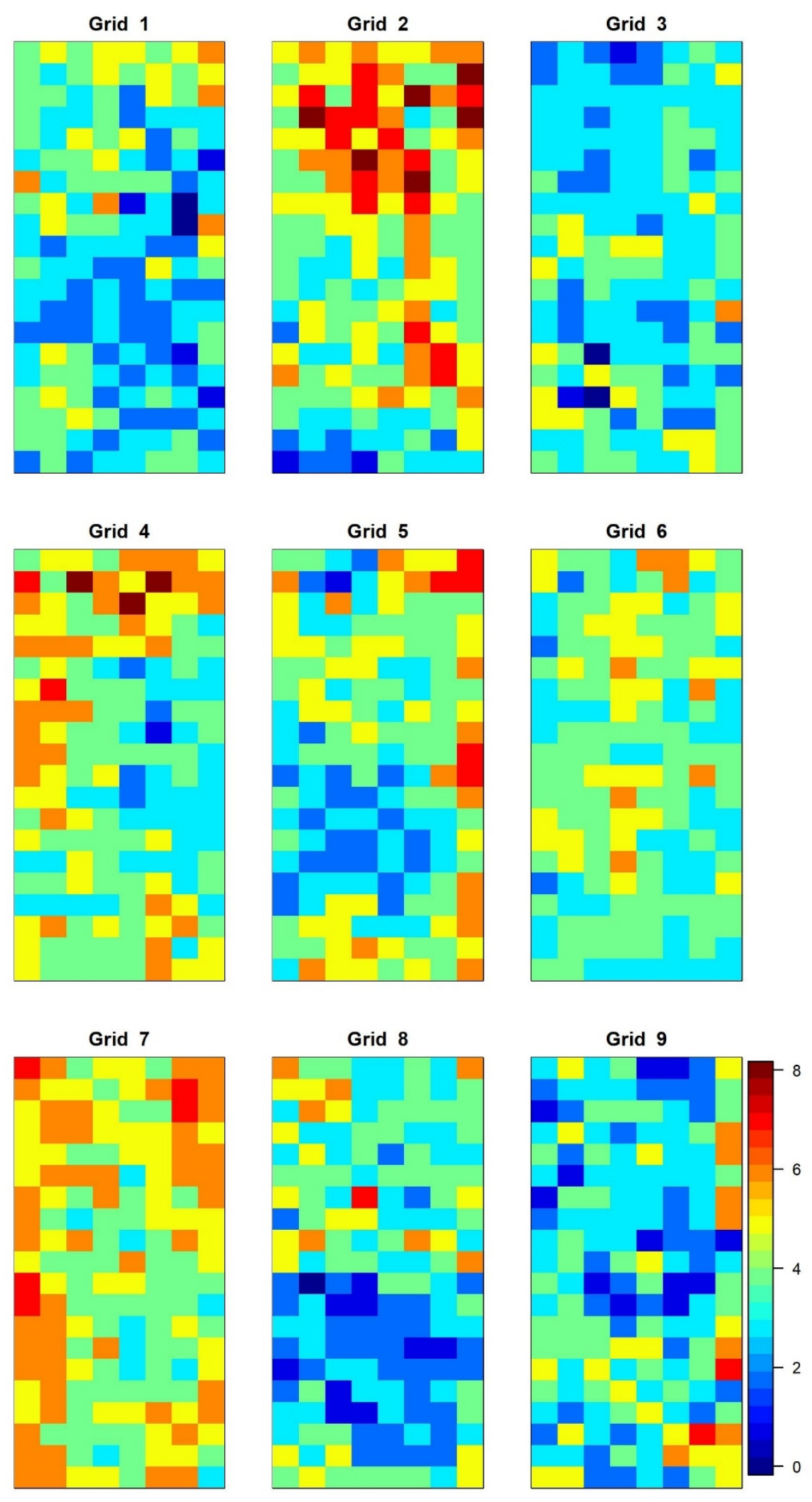
Figure 3
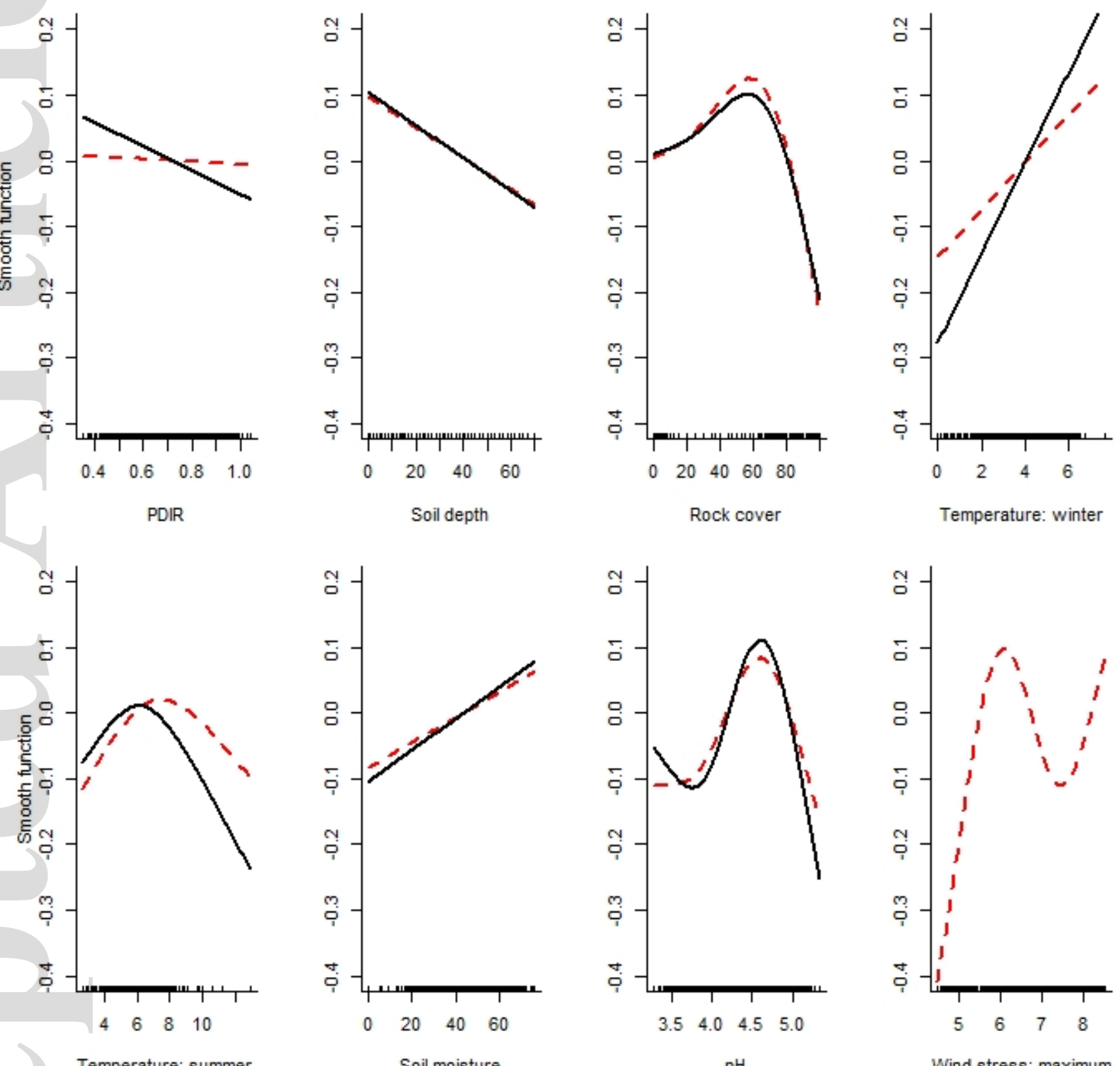

Temperature: summer

Soil moisture

$\mathrm{pH}$

Figure 4 

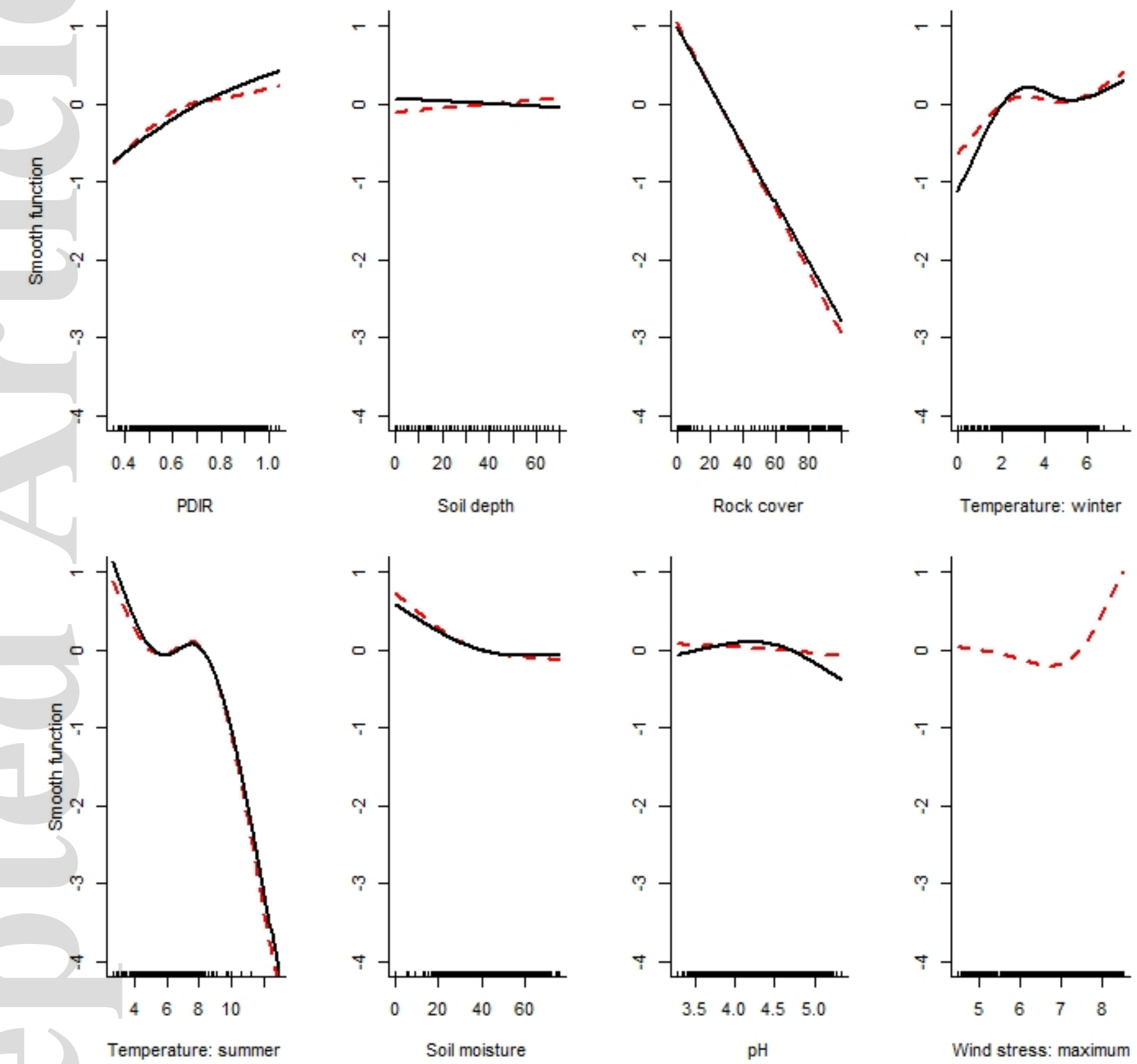

Figure 5 


\section{a}

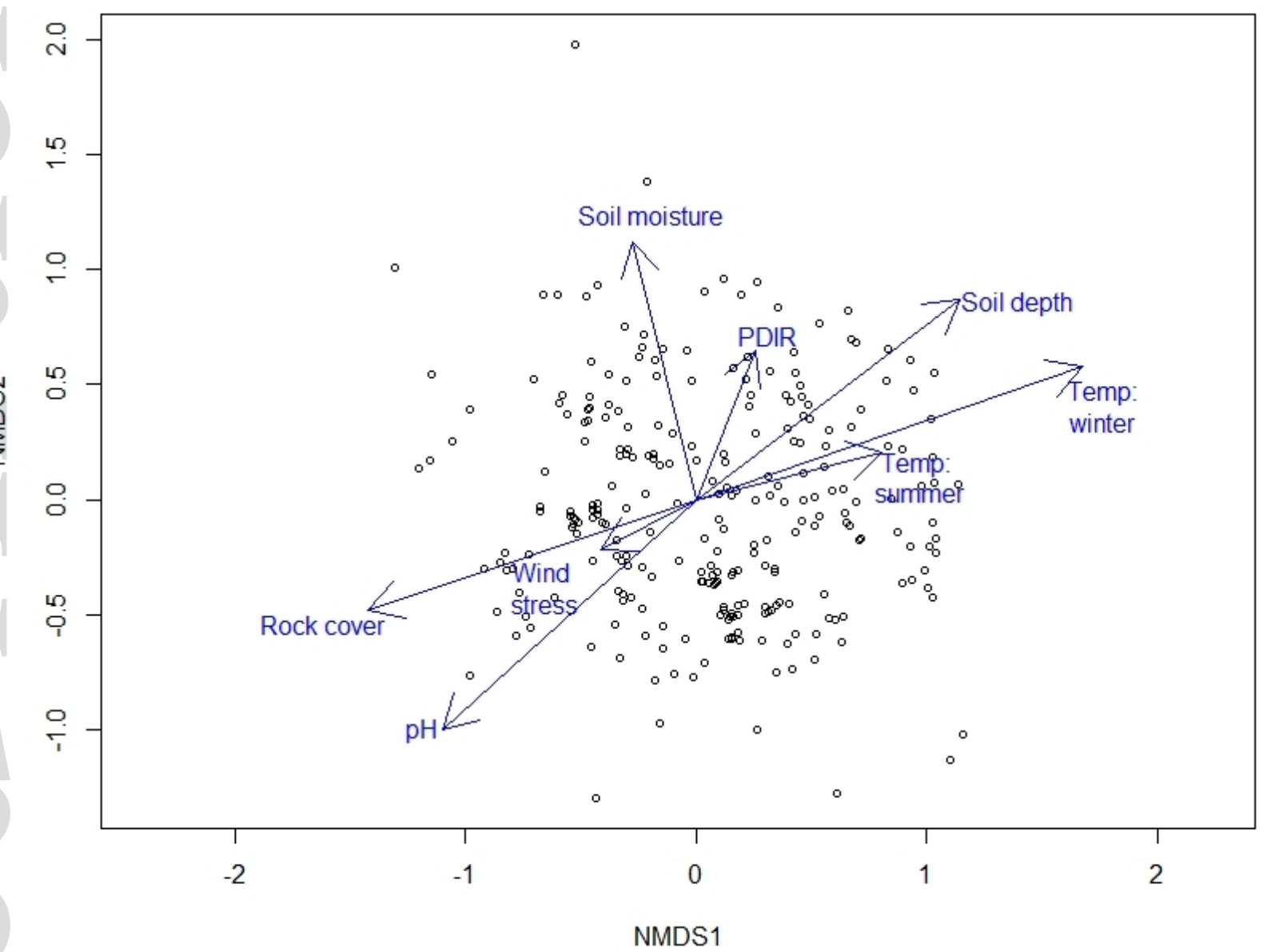

b

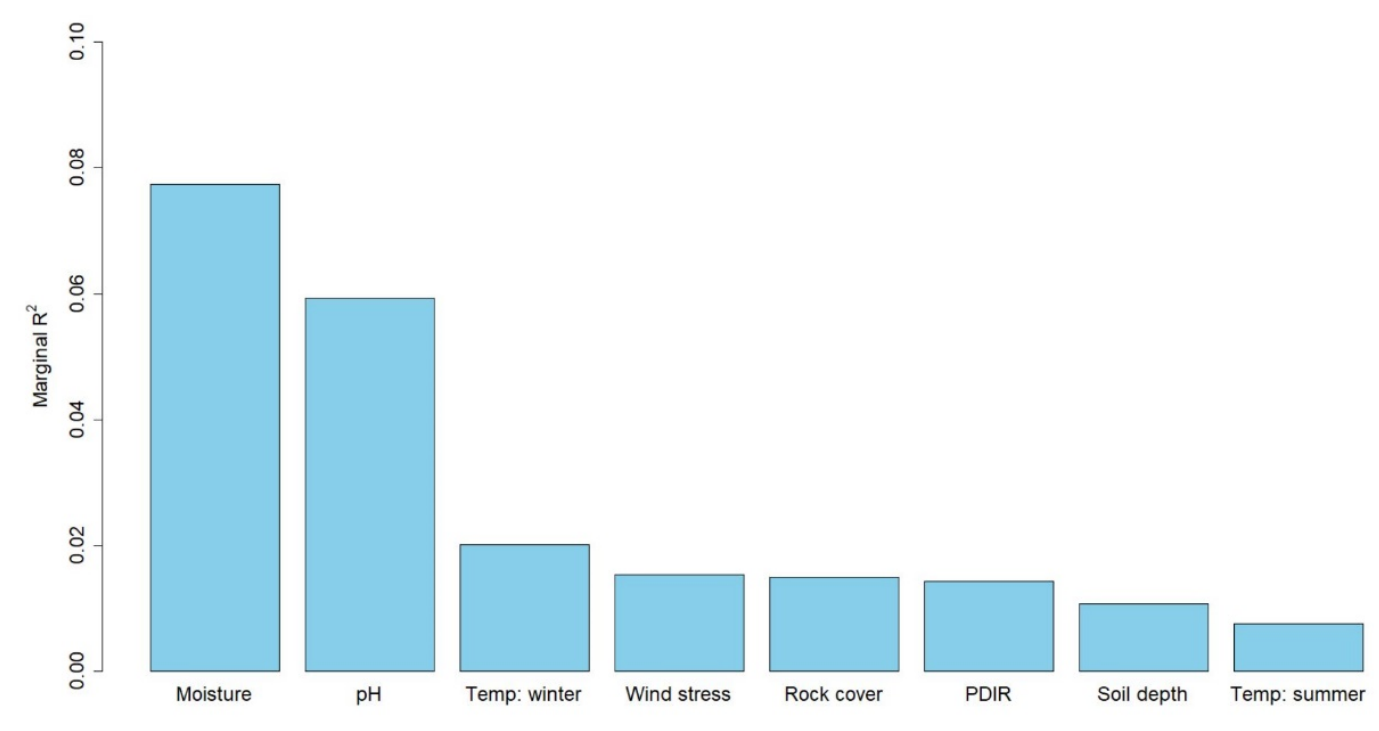

Figure 6

This article is protected by copyright. All rights reserved 